\title{
Assessment and Management of the Georges Bank Cod Fishery: An Historical Review and Evaluation
}

\author{
Fredric M. Serchuk and Susan E. Wigley \\ National Oceanic and Atmospheric Administration \\ Northeast Fisheries Science Center, National Marine Fisheries Service \\ Woods Hole, Massachusetts 02543 USA
}

\begin{abstract}
Atlantic cod (Gadus morhua) in the Georges Bank region have been commercially exploited since the 17th century and continue as the mainstay of the New England commercial and recreational groundfish fisheries today. Throughout most of its history, the Georges Bank cod fishery was unregulated and growth in the fishery did not appear to exceed resource potential. An historical review of assessment activities and management programs reveals that the Georges Bank cod stock seemed resilient to heavy fishing pressure until the early- and mid-1980s when landings, fishing effort and fishing mortality approached or attained record-high levels. Management plans enacted independently by the USA and Canada under extended fisheries jurisdiction have not been very successful in preventing overfishing of Georges Bank cod. Different management objectives and a lack of compatible management strategies and approaches between the two countries have exacerbated the situation. Both the USA and Canada now recognize that cooperative and coordinated management actions are needed to avert overfishing and rebuild transboundary fishery resources, including Georges Bank cod.
\end{abstract}

\section{Introduction}

"We left him at the seaside and returned to our ship where, in five or six hours absence, we had pestered our ship so with codfish that we threw numbers of them overboard again; and surely, I am persuaded that in the months of March, April, and May, there is upon this coast (Cape Cod) better fishing, and in as great plenty, as in Newfoundland. For the schools of mackerel, herrings, cod, and other fish that we daily saw as we went and came from shore, were wonderful..." John Brereton, 1602

The early history of fishing in New England is the history of the fishery for Atlantic cod, (Gadus morhua). Cod fishing was a principal occupation and source of food for the early colonists and dried salt cod subsequently became a major commodity in commerce and international trade. The earliest fisheries in the 1600s occurred in the local waters off Maine and Massachusetts but by the early-1700s New England vessels had begun to fish the offshore banks (Jensen and Murray, 1965). The first trip with cod from Georges Bank was landed in 1748 in Marblehead, Massachusetts and cod catches from Georges Bank have been a major component of the USA groundfish fishery since the late 1800s (Goode and Collins, 1887). The course of American history has been influenced more by cod than any other fish (Ryan, 1979) and a large wooden carving of the "Sacred Cod" has hung in the Massachusetts State House since 1784 as a symbol of the source of original wealth of Massachusetts and the Nation.

Although catches of cod have fluctuated over the centuries, cod is no less important now than in former times. Cod is presently the mainstay of the USA commercial groundfish fishery on Georges Bank and, in the past two decades, has accounted for more catch (by weight) than any other groundfish species taken in the fishery. During 1988-90, USA Georges Bank cod landings (26 500 tons per year) exceeded the total USA landings of haddock, redfish, winter flounder and yellowtail flounder combined. Additionally, a significant recreational fishery for cod exists; USA recreational landings of cod from the Georges Bank stock have averaged about 2000 tons per year since 1986 (Recreational Fishery Statistics Working Group, MS 1992).

In this paper, an historical review of the Georges Bank cod stock and fishery is presented, and information provided on changes in the status of the stock as reflected by indices of abundance and stock assessment results. The management history of the Georges Bank stock is also reviewed, with 
particular emphasis on the effectiveness of (1) international management activities during 1950-76, and (2) USA and Canadian domestic management activities enacted under extended fisheries jurisdiction from 1977 onward.

\section{Distribution and Stock Structure}

"On the shores of the United States we find fish of different kinds each supplying a certain proportion of the inhabitants. These are restrained by some laws in nature to their own feeding ground; they do not invade the rights of others, nor are their rights infringed by any. The cod-fish which occupy the banks lying between the latitudes of 41 and 45 , are very different on the different banks, and are kept so distinct, and are so similar on the respective banks that a man acquainted with the fishing business will separate those caught on one bank from those caught on another with as much ease as we separate the apple from the pear". Hon. General Lincoln, 1791.

Cod occur in the Northwest Atlantic from Greenland to North Carolina (Wise, 1958; Scott and Scott, 1988), with the highest concentrations in USA waters occurring on Georges Bank and in the Gulf of Maine. Within USA waters, three or possibly four major groupings of cod have been generally recognized: (1) Georges Bank, (2) Gulf of Maine and (3) one or two groups in the Southern New EnglandMiddle Atlantic area (Wise, 1963; Serchuk and Wigley, MS 1986). Based on tagging studies (Smith, 1902; Schroeder, 1930; North American Council on Fishery Investigations, 1932; 1935; Wise, 1963), parasite infestations (Sherman and Wise, 1961), spawning time data (Colton et al., 1979), and growth rate analyses (Penttila and Gifford, 1976; Serchuk and Wood, MS 1979), minimal interchange of cod occurs between the Gulf of Maine and Georges Bank groups, but extensive mixing prevails between cod on Georges Bank and in the Southern New England-Middle Atlantic region. A seasonal southwesterly movement of cod from the South Channel area of Georges Bank occurs in autumn followed by a northeasterly return in spring. Wise(1963) proposed that the autumn movement was not a migration of Georges Bank fish [as concluded by Schroeder (1930)] but rather a return of Southern New England-Middle Atlantic fish to their native grounds for winter spawning. The presence of ripe spawning individuals off the New Jersey coast (Smith, 1902; Schroeder, 1930; Wise, 1958) and the occurrence of cod eggs and larvae as far south as North Carolina (Schroeder, 1930; Berrien et al., 1978) seemingly suggest that cod in the Middle Atlantic may comprise a genetically distinct subpopulation, separate from the groupings further north. However, the origin and fate of Middle Atlantic cod eggs and larvae have yet to be determined, and hence the existence of a Middle Atlantic subpopulation remains to be confirmed. Serchuk and Wood (MS 1979) found strong affinities between Georges Bank and Southern New England-Middle Atlantic cod based on growth rates, research vessel survey catch and abundance patterns, recruitment trends, and commercial catch size/age distributions. Based on these findings, and the relative scarcity of juvenile cod in inshore and offshore research vessel surveys in the Southern New England-Middle Atlantic region, Serchuk and Wood (MS 1979) hypothesized that either the southerly populations were not selfsustaining or that offspring from the southern spawning move north as ichthyoplankton or larval nekton, and return south several years later as adults.

Cod on Georges Bank and in Southern New England [ICNAF/NAFO Div. $5 Z$ (eastern Georges Bank to Long Island, New York); Fig. 1] have been managed separately from cod in the Gulf of Maine (Div. 5Y) since 1972. With the implementation of extended fisheries jurisdiction in 1977, the USA and Canada assumed separate responsibilities for the management of Georges Bank cod. Due to the pronounced demographic similarities between GeorgesBank and Southern New England-Middle Atlantic cod, the two groups have been treated as a single 'Georges Bank' stock unit (Div. $5 Z$ and Subarea 6) by the USA since 1977. From 1983 through 1988, Canada similarly considered the 'Georges Bank' stock as encompassing the cod in Div. $5 Z$ and Subarea 6 (Bowen, MS 1987; Hunt, MS 1988). In 1989, Canada re-examined the definitions of management units for groundfish species on Georges Bank (in light of the separate USA and Canadian management systems and the delimitation in 1984 of a maritime boundary between the USA and Canada in the Gulf of Maine/Georges Bank area), and concluded that the 'Georges Bank' cod stock could be partitioned into two management units: (1) eastern Georges Bank cod (unit areas 5Zj and 5Zm; Fig. 1); and (2) central and western Georges Bank cod (the remainder of Div. $5 Z$ and Subarea 6) (Hunt, MS 1989). As such, from 1989 onwards, Canada has treated the cod on Georges Bank as being comprised of two separate units (CAFSAC, MS 1989; Halliday and Pinhorn, 1990).

\section{Commerical Fishery Landings}

"The successful result of a trip to George's Bank for codfish is largely dependent upon the exertions of each individual; men are, therefore, required for that fishery in whose natures is combined hardihood, doggedness of purpose, and bravery." G.B.Goode and J.W.Collins, 1887.

Technological innovations and changes in consumer preferences have strongly influenced commercial landings of cod from Georges Bank (Jensen, 

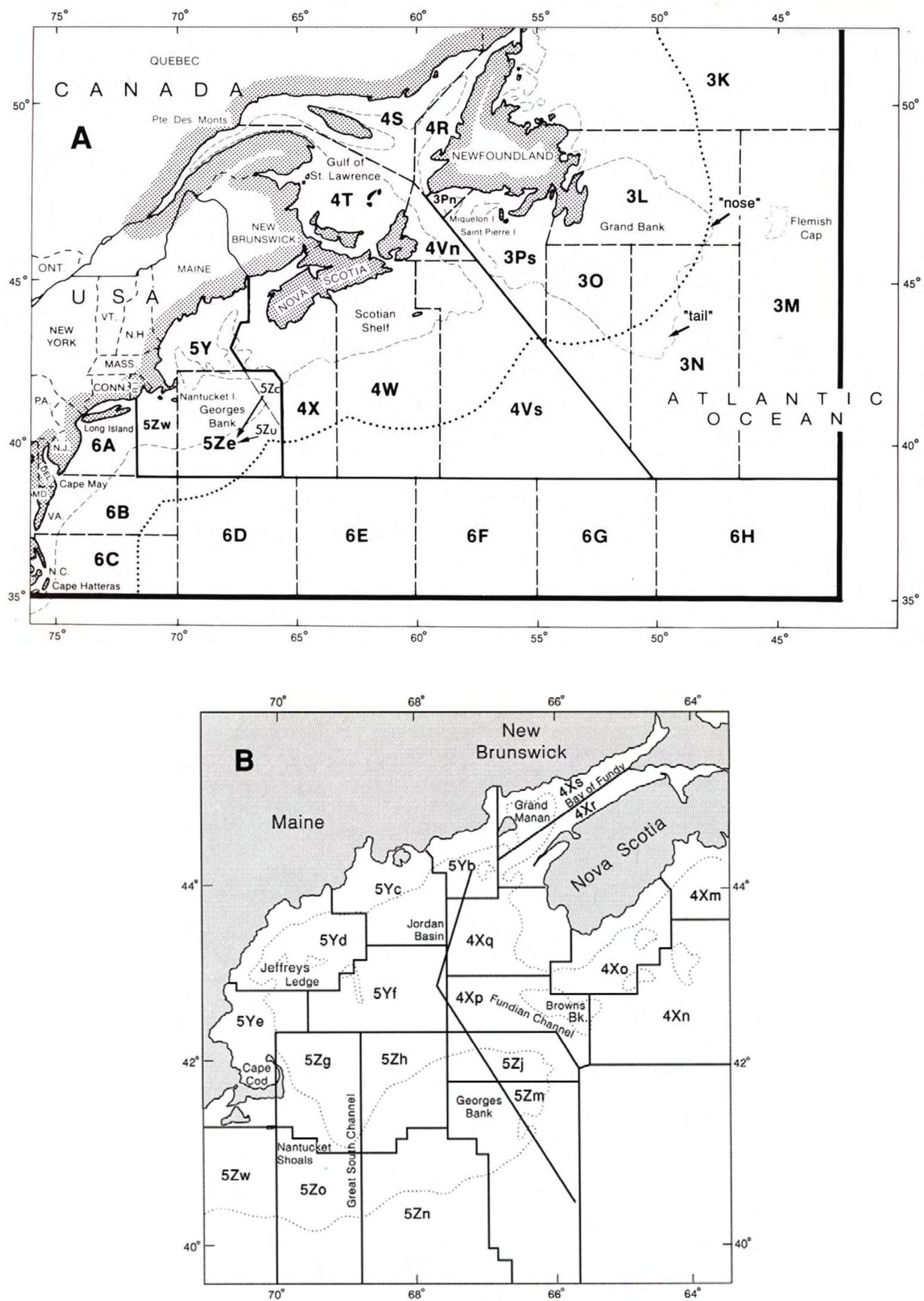

Fig. 1. (A) Map showing NAFO Subareas 3-6, and (B) statistical unit areas on Georges Bank. 
1972). Prior to the early-1900s, most of the catch was taken by handlining from schooners and longlining from dories. Although labor intensive, a skillful schooner crew of 8-12 men, under favorable conditions, might catch between 20 000-30 $000 \mathrm{lb}$ of cod in a day (Goode and Collins, 1887). The dory-schooner fishery for cod on Georges Bank reached its heyday during the last quarter of the 19th century; in 1880, more than 12000 tons of cod were taken by the 163 vessels engaged in the Georges Bank fishery.

By the early-1900s, however, the character of the Georges Bank cod fishery had markedly changed. With the introduction of steam and dieselpowered vessels, otter trawling, power equipment, and low-cost ice making and refrigeration technology, the fishing fleet became much more mobile and efficient. In response to increased consumer demand for fresh fish, the focus of the cod fishery switched from providing salt cod to landing iced, fresh product (German, 1987).

A continuous record of commercial landings statistics of Georges Bank cod is available from 1893 onward (1893-1931, Subarea 5; 1932-59, Div. 5Z; 1960-90, Div. $5 Z$ and Subarea 6). Historically, the fishery can be divided into five time-periods (Fig. 2):

1) an early era from 1893 to 1914 in which record-high landings (>60 000 tons) in 1895 and 1906 were followed by about 10 years of sharply reduced catches. The elevated landings in 1906 and 1907 probably reflects the introduction of otter trawling for cod using steam-powered vessels (Jensen and Murray, 1965; Jensen, 1972).

2) a later period from 1915 to 1940 in which annual landings fluctuated between 20000 40000 tons and during which cod was generally taken as a by-catch in the Georges Bank haddock fishery. The development, after World War I, of a packaged fish trade for quick-frozen haddock fillets resulted in a substantial increase in Georges Bank haddock landings (Fig. 3) and the preeminence of haddock over cod in the marketplace (Sette and Fiedler, 1929; Jensen, 1967).

3) the 1940-60 period when landings declined, reaching a record-low of 8100 tons in 1953. During these years, fishing activity for cod on Georges Bank diminished due to the menace of World War II submarines (in the early part of the period) and a redirection of fleet effort towards the relatively more abundant haddock resource.
4) the1960-76 period in which Canadian and distant-water fleet fisheries for Georges Bank cod developed (Table 1; Fig. 4). Fishing effort for cod strikingly increased during this period and resulted in a five-fold increase in landings between 1960 and 1966 (11 000 to 53000 tons). However, landings sharply declined afterward reaching only 20000 tons in 1976.

5) the most recent period beginning in 1977 with the implementation of extended fisheries jurisdiction by both the USA and Canada. Total cod landings (solely USA and Canadian) from Georges Bank doubled between 1977 and 1982 (27 000 to 57000 tons), declined to only 26000 tons in 1986, but have since increased to 42500 tons in 1990.

\section{Recreational Fishery Landings}

"It is not unusual for an angler to haul up a fish that weighs 40 or 50 pounds and many recreational fishermen struggle home with gunny sacks brimming with 100 pounds or more of cod after a day at sea." Albert Jensen, 1974.

Recreational fisheries for cod in USA waters have existed for many decades but information on catches has only been collected during the past 30 years. Recreational catch estimates of cod are available from a set of national saltwater angling surveys conducted in 1960, 1965, 1970 and 1974, and from a newer series of marine recreational fishery statistics surveys conducted annually since 1979. The latter series of surveys is considered the more reliable since a standardized statistical design is employed involving a combination of household telephone interviews and on-site field surveys.

Estimated recreational cod catches (including those reportedly caught and subsequently released alive) have ranged between 3450 tons (1986) and 16300 tons (1970) (Table 2; Fig. 5). The highest estimates were derived prior to 1979 but must be considered tentative due to methodological weaknesses and differences in survey procedures in these years (United States Department of Commerce, 1979). Between 1981 and 1985, annual recreational cod landings exhibited little variability; apart from 1984, annual catches ranged between $8000-9000$ tons, and averaged 8500 tons per year. Recreational catches declined in 1986 and 1987 to less than 4000 tons, but have since increased to between 5000 tons and 7700 tons.

Preliminary estimates of recreational catches of cod by stock unit have recently been derived using 


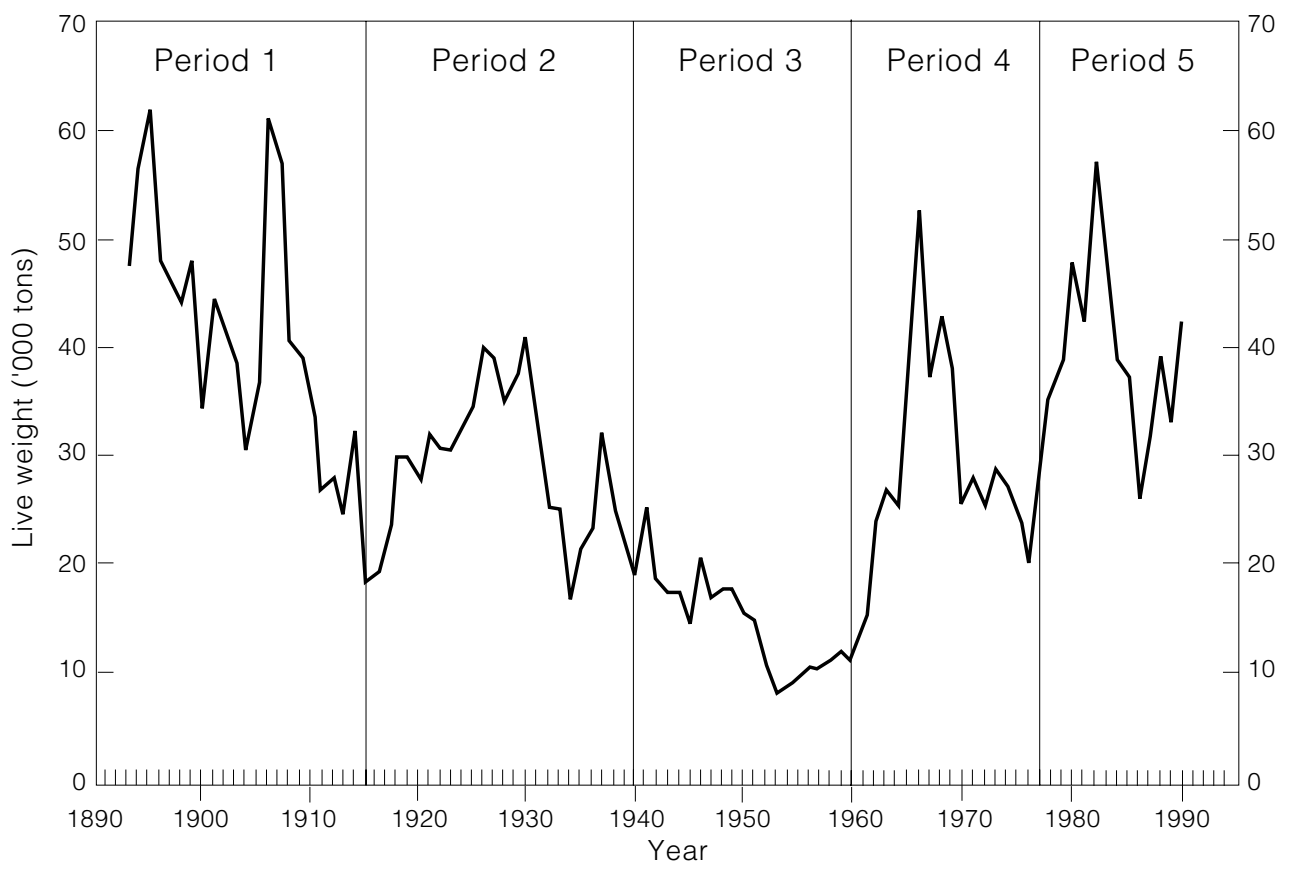

Fig. 2. Total commercial landings of cod from Georges Bank, 1893-1990.

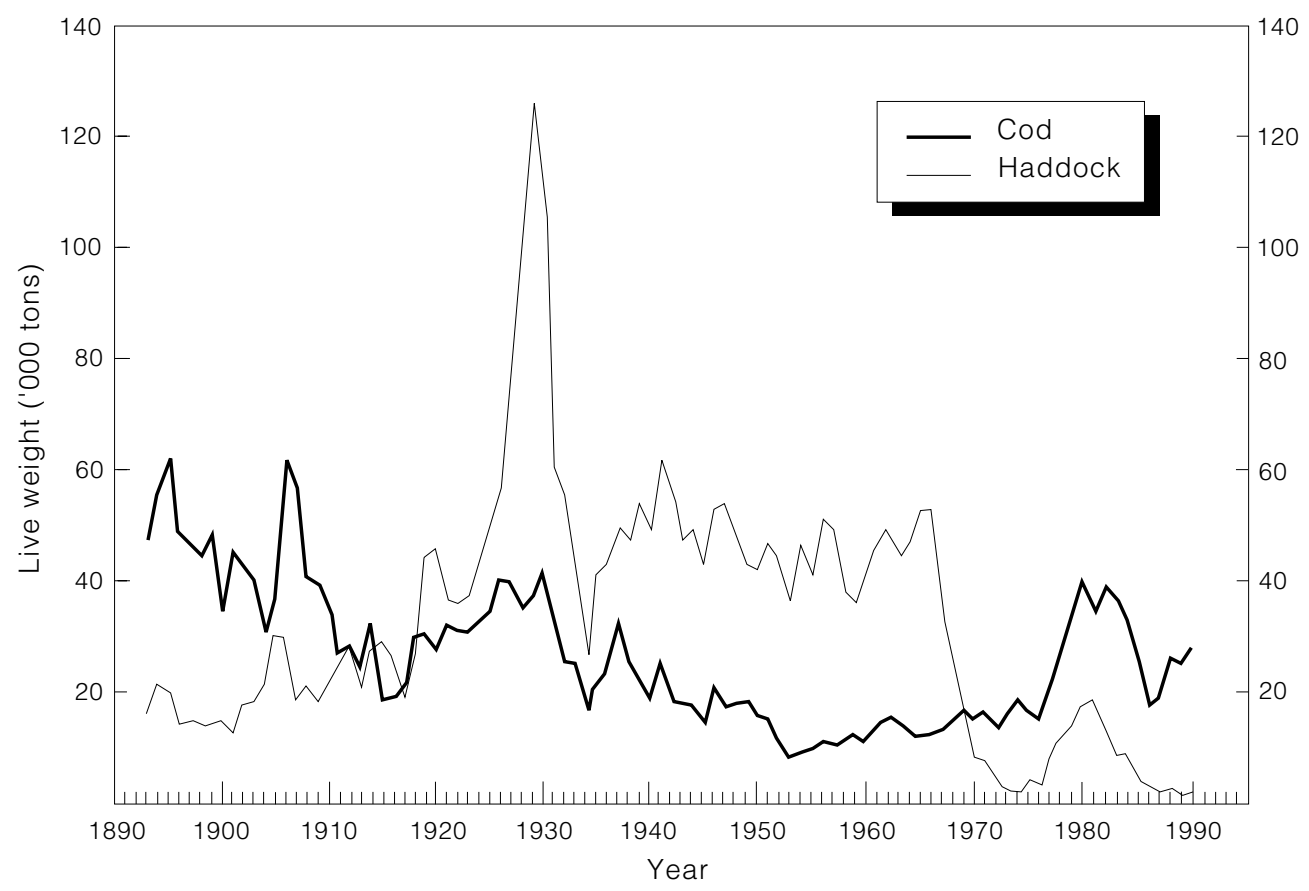

Fig. 3. USA commercial landings of cod and haddock from Georges Bank, 1893-1990.

landing site information (from the field surveys) to allocate catches between the Gulf of Maine and Georges Bank stocks (Recreational Fisheries Statistics Working Group, MS 1992). Between 1981 and 1985, estimated catches from the Georges Bank stock (Div. $5 Z$ and Subarea 6) ranged between 2400 tons and 5300 tons and averaged 4 400 tons per year (Table 2). Since 1986, however, recreational catches of Georges Bank cod have averaged just 2000 tons per year, and accounted (apart from 1988) for only a third of the total USA recreational cod landings (Fig. 5). 
TABLE 1. Commercial landings (tons, live) of Atlantic cod from Georges Bank and South (Div. $5 Z$ and Subarea 6), 1960-90.

\begin{tabular}{|c|c|c|c|c|c|c|c|}
\hline \multirow[b]{2}{*}{ Year } & \multicolumn{5}{|c|}{ Country } & \multirow[b]{2}{*}{ Other } & \multirow[b]{2}{*}{ Total } \\
\hline & USA & Canada & USSR & Spain & Poland & & \\
\hline 1960 & 10834 & 19 & - & - & - & - & 10853 \\
\hline 1961 & 14453 & 223 & 55 & - & - & - & 14731 \\
\hline 1962 & 15637 & 2404 & 5302 & - & 143 & - & 23486 \\
\hline 1963 & 14139 & 7832 & 5217 & - & - & 1 & 27189 \\
\hline 1964 & 12325 & 7108 & 5428 & 18 & 48 & 238 & 25165 \\
\hline 1965 & 11410 & 10598 & 14415 & 59 & 1851 & - & 38333 \\
\hline 1966 & 11990 & 15601 & 16830 & 8375 & 269 & 69 & 53134 \\
\hline 1967 & 13157 & 8232 & 511 & 14730 & - & 122 & 36752 \\
\hline 1968 & 15279 & 9127 & 1459 & 14622 & 2611 & 38 & 43136 \\
\hline 1969 & 16782 & 5997 & 646 & 13597 & 798 & 119 & 37939 \\
\hline 1970 & 14899 & 2583 & 364 & 6874 & 784 & 148 & 25652 \\
\hline 1971 & 16178 & 2979 & 1270 & 7460 & 256 & 36 & 28179 \\
\hline 1972 & 13406 & 2545 & 1878 & 6704 & 271 & 255 & 25059 \\
\hline 1973 & 16202 & 3220 & 2977 & 5980 & 430 & 114 & 28923 \\
\hline 1974 & 18377 & 1374 & 476 & 6370 & 566 & 168 & 27331 \\
\hline 1975 & 16017 & 1847 & 2403 & 4044 & 481 & 216 & 25008 \\
\hline 1976 & 14906 & 2328 & 933 & 1633 & 90 & 36 & 19926 \\
\hline 1977 & 21138 & 6173 & 54 & 2 & - & - & 27367 \\
\hline 1978 & 26579 & 8778 & - & - & - & - & 35357 \\
\hline 1979 & 32645 & 5978 & - & - & - & - & 38623 \\
\hline 1980 & 40053 & 8063 & - & - & - & - & 48116 \\
\hline 1981 & 33849 & 8499 & - & - & - & - & 42348 \\
\hline 1982 & 39333 & 17824 & - & - & - & - & 57157 \\
\hline 1983 & 36756 & 12130 & - & - & - & - & 48886 \\
\hline 1984 & 32915 & 5763 & - & - & - & - & 38678 \\
\hline 1985 & 26828 & 10443 & - & - & - & - & 37271 \\
\hline 1986 & 17490 & 8411 & - & - & - & - & 25901 \\
\hline 1987 & 19035 & 11845 & - & - & - & - & 30880 \\
\hline 1988 & 26310 & 12932 & - & - & - & - & 39242 \\
\hline 1989 & 25097 & 8001 & - & - & - & - & 33098 \\
\hline $1990^{a}$ & 28193 & 14310 & - & - & - & - & 42503 \\
\hline
\end{tabular}

arovisional.

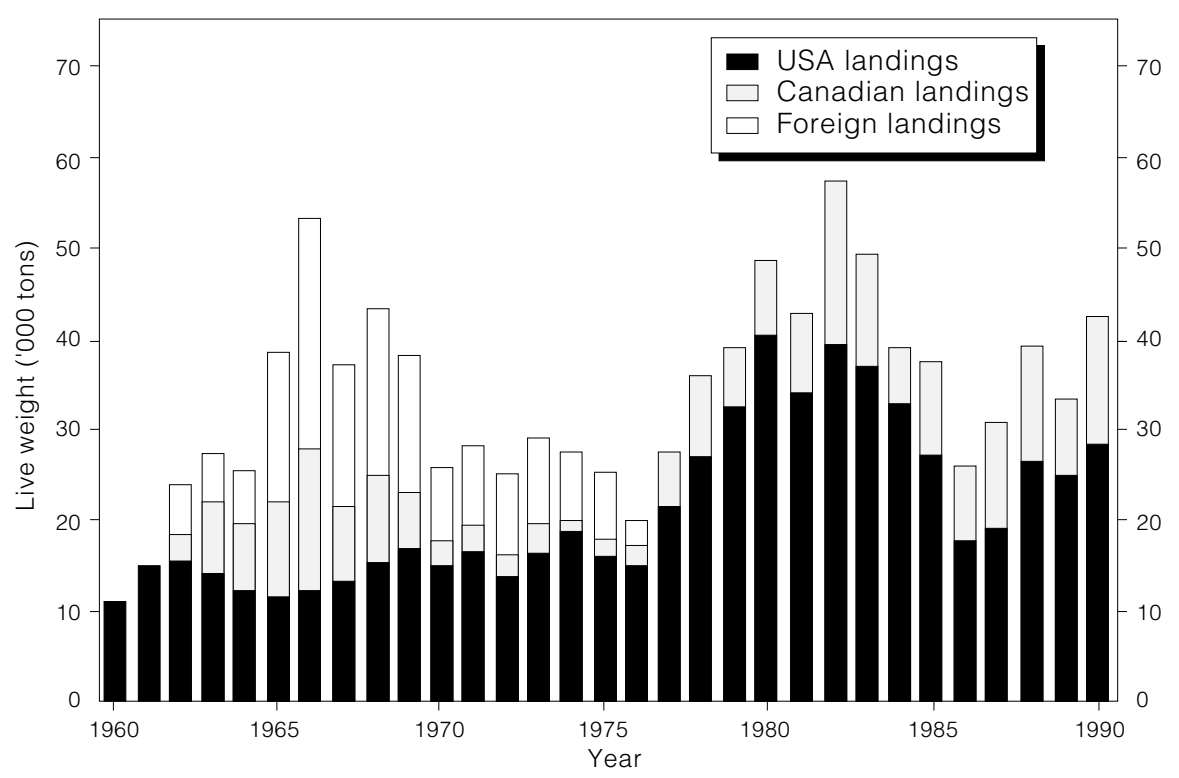

Fig. 4. Total commercial landings of cod from Georges Bank (Div. $5 Z$ and Subarea 6), 1960-90. 
Most of the recreational catch of $\operatorname{cod}(>70 \%)$ is taken beyond 3 miles from the coast (i.e. in 'federal' waters). More than $95 \%$ of the catch is taken by party/charter and private/rental boats, with landings in Massachusetts exceeding those from any other State.

\section{Stock Assessment and Management}

"Of all the various fisheries formerly prosecuted directly off the coast of New England, north of Cape
Cod, the depreciation in that of the Cod appears to be of the greatest economical importance." S. F. Baird, 1874.

"Cod, though heavily exploited, nevertheless support the most stable and continuous of all Georges fisheries. Their biology apparently buffers them against strong population changes under the pressure of fishing." R.C. Hennemuth and S. Rockwell, 1987.

TABLE 2. Estimated number ('000) and live weight (tons) of Atlantic cod caught by marine recreational fishermen, in 1960, 1965, 1970, 1974 and 1979-90.

\begin{tabular}{|c|c|c|c|c|c|c|c|c|}
\hline \multirow[b]{2}{*}{ Year } & \multicolumn{2}{|c|}{ North Atlantic ${ }^{a, b}$} & \multicolumn{2}{|c|}{ Mid-Atlantic ${ }^{b}$} & \multicolumn{2}{|c|}{ All Regions } & \multicolumn{2}{|c|}{ Georges Bank Stock $^{c}$} \\
\hline & Numbers & Weight & Numbers & Weight & Numbers & Weight & Numbers & Weight \\
\hline 1960 & 3998 & 11426 & 793 & 2590 & 4791 & 14016 & \multicolumn{2}{|c|}{ Not Estimated } \\
\hline 1965 & 4970 & 13144 & 62 & 421 & 5032 & 13565 & \multicolumn{2}{|c|}{ Not Estimated } \\
\hline 1970 & 3690 & 16188 & 154 & 104 & 3844 & 16292 & \multirow{2}{*}{\multicolumn{2}{|c|}{$\begin{array}{l}\text { Not Estimated } \\
\text { Not Estimated }\end{array}$}} \\
\hline 1974 & 2155 & 8566 & 746 & 3802 & 2901 & 12368 & & \\
\hline 1979 & 3083 & 3762 & 8 & 55 & 3091 & 3817 & 393 & 580 \\
\hline 1980 & 2403 & 6376 & 36 & 9 & 2439 & 6385 & 186 & 471 \\
\hline 1981 & 4440 & 7281 & 482 & 1367 & 4922 & 8648 & 1605 & 4677 \\
\hline 1982 & 2663 & 4378 & 586 & 3633 & 3249 & 8011 & 1453 & 5296 \\
\hline 1983 & 3511 & 7432 & 244 & 852 & 3755 & 8284 & 1693 & 4920 \\
\hline 1984 & 2463 & 5061 & 102 & 330 & 2565 & 5391 & 832 & 2406 \\
\hline 1985 & 3611 & 8644 & 62 & 338 & 3673 & 8982 & 1998 & 4635 \\
\hline 1986 & 1493 & 3261 & 56 & 187 & 1549 & 3448 & 331 & 1092 \\
\hline 1987 & 1851 & 3217 & 158 & 464 & 2009 & 3681 & 467 & 1168 \\
\hline 1988 & 2096 & 4873 & 895 & 2781 & 2991 & 7654 & 1494 & 4284 \\
\hline 1989 & 2133 & 3822 & 330 & 1208 & 2463 & 5030 & 538 & 1875 \\
\hline 1990 & 2484 & 4753 & 228 & 717 & 2712 & 5470 & 690 & 1696 \\
\hline
\end{tabular}

${ }^{a}$ During 1960, 1965 and 1970 marine recreational fishery statistics surveys in 'North Atlantic' included the States of Maine to New York; in subsequent surveys, 'North Atlantic' included only the States of Maine to Connecticut (i.e. excluding New York).

${ }^{b}$ For surveys conducted in 1979 and afterward, total weight caught was derived by multiplying the number of cod caught in each region by the mean weight of cod landed in whole form in each region (Type A catch) obtained from intercept (creel) survey sampling.

${ }^{c}$ From Recreational Fishery Statistics Working Group (MS 1992).

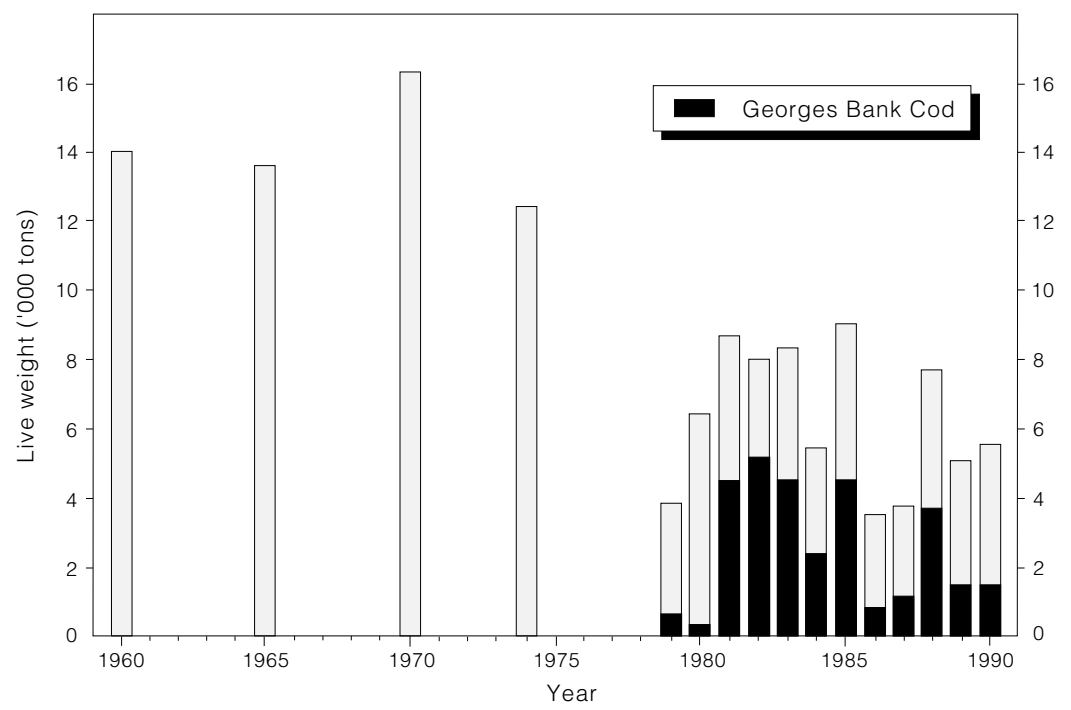

Fig. 5. Estimated USA recreational catches of Atlantic cod in 1960, 1965, 1970, 1974 and 1979-90. Estimated annual recreational catches of cod from the Georges Bank stock are shown for 1979-90. 
Early Evaluations (before 1965). Prior to the development in the 1930s and 1940s of formalized systems for the collection of comprehensive fishery statistics (North American Council on Fishery Investigations, 1932; 1935; Rounsefell, 1948), changes in the stock abundance of cod (and other species) could generally only be evaluated from anecdotal reports or from trends in catches, by port or fishing ground. Anecdotal reports in the early-1870s of a short supply of cod in the inshore region of the Gulf of Maine prompted the first study of the effects of human activity on fishery resources (Baird, 1874). Although Baird's conclusion that cod had declined due to reduced prey abundance (alewives and herring) caused by the building of dams was (in hindsight) incorrect (Graham, 1970), his efforts led to the establishment of the US fisheries research laboratory at Woods Hole in 1875 where scientific programs were initiated to investigate fluctuations in commercial fish stocks and their causes (Baird, 1873). The earliest programs relating to cod focused on artificial culture and stocking of fry to enhance natural production and on determining the distribution and migration of cod via tagging (Smith, 1902). These and subsequent investigations [especially the studies by Fish (1928) and Schroeder (1930)] provided baseline information on the life history aspects of cod off the New England coast.

The first scientific inquiry of the effect of fishing on the abundance of fish stocks on Georges Bank was conducted in 1913, as part of a study to evaluate the impacts of otter trawling (Alexander et al. ,
1915). Based on analysis of trends in catch-perunit-effort (CPUE) during 1891-1914 of cod, haddock and hake, no evidence was found that any of the demersal stocks on Georges Bank were being overfished. Nonetheless, for Georges Bank cod, the study indicated that line trawl (e.g. Iongline) CPUE had declined by $45 \%$ between 1908 and 1914 , and that CPUE in 1914 was a record-low value (Fig. 6).

The study by Alexander et al. (1915) raised concerns that expansion of the Georges Bank otter trawl fishery might result in substantial discards of small fish. Size composition data collected from otter trawlers fishing Georges Bank in 1913 revealed that $30-40 \%$ (by weight) of the cod and haddock captured were too small to market, and that the average size of fish landed by otter trawlers was smaller than that by line trawlers. However, the study recommended against increasing the codend mesh size (which was then 2.5 inches) as a way to allow greater escapement of small fish since it was felt that (1) meshes tended to close as fish were caught by the trawl, (2) fish in the cod-end blocked escape, (3) fish did not escape until haulback when escapement was minimal and (4) greater numbers of fish would be gilled with larger meshes. The study also discounted, as feasible regulatory methods, a ban on otter trawling or restrictions on the number of vessels or trawls in the fishery. Instead, area restrictions for otter trawlers were proposed but were not supported by the fishing industry and hence never implemented (Herrington, 1935).

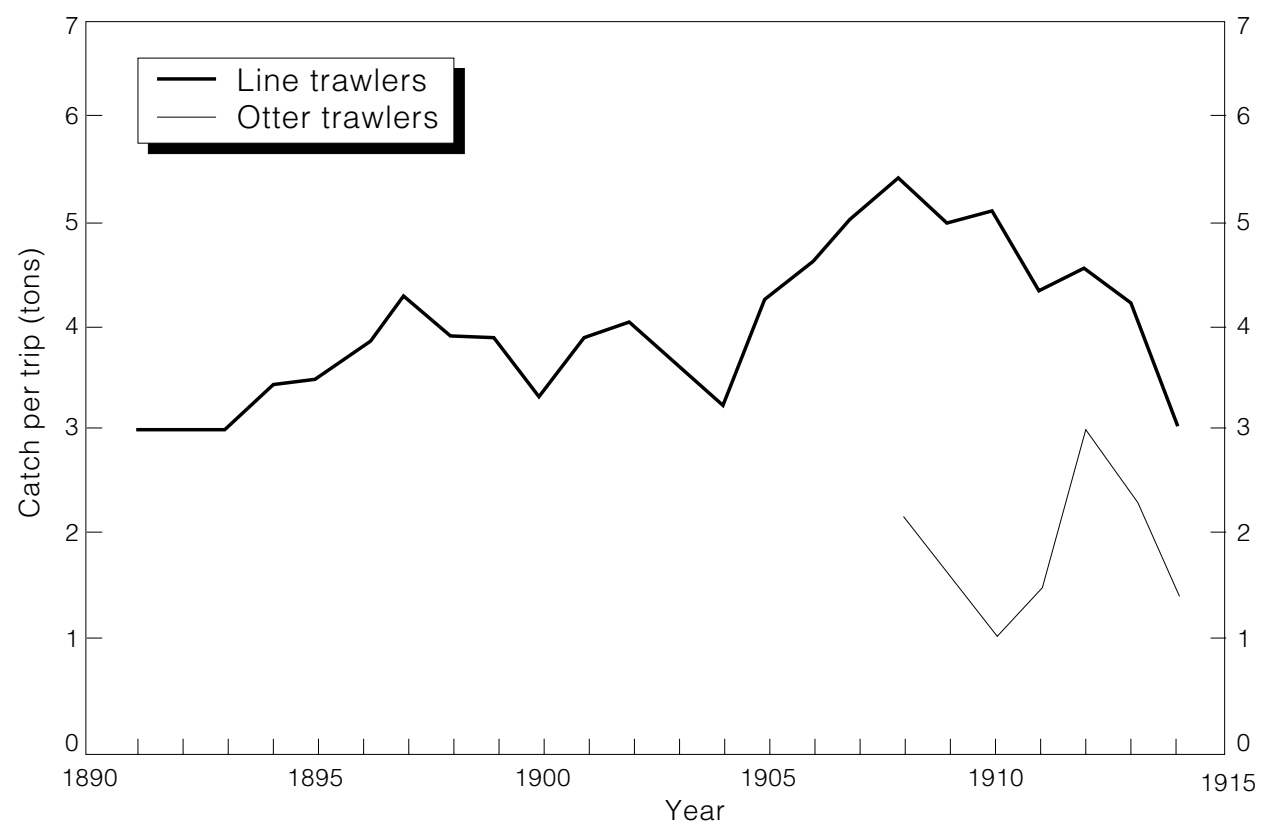

Fig. 6. Commercial catch per trip of Georges Bank cod by line trawl and otter trawl vessels, 1891 - 1914 (from Alexander et al., 1915). 
Between World War I and II, Georges Bank cod landings ranged between 20000 and 40000 tons, but most scientific attention during the period was focused on Georges Bank haddock. Haddock landings had dropped from over 120000 tons in 1929 to 28000 tons in 1934 (Fig. 3) at a time when the USA otter-trawl fleet had grown from 26 to 323 vessels (Sette and Fiedler, 1929; Herrington, 1932). Discarding of tremendous quantities of small fish was implicated as a major cause for the reduced landings. Sea sampling observations and mesh size experiments in the early-1930s indicated that up to $75 \%$ of the haddock caught by otter trawlers on Georges Bank were nonmarketable $(<35 \mathrm{~cm},<0.7$ $\mathrm{kg}$ ), but that the capture of undersized fish (including cod) could be markedly reduced by use of larger cod-end mesh sizes. It was recommended that industry adopt a minimum mesh size of at least 4.75 inches $(121 \mathrm{~mm})$ and that a mesh size of 5 to 5.25 inches (127-133 $\mathrm{mm}$ ) would be even more beneficial (Herrington, 1935). Although some fishermen adopted larger mesh sizes voluntarily, complete noncompulsory use of larger meshes was not attained since larger meshes allowed small quantities of marketable-sized fish to escape (Graham, 1970). Nearly 20 years elapsed before minimum mesh regulations (4.5 inches, $114 \mathrm{~mm}$ ) were formally implemented in the Georges Bank haddock and cod fisheries (in 1953 and 1955, respectively) under the International Commission for the Northwest Atlantic Fisheries (ICNAF) founded in 1949. During the intervening period, annual discards of haddock exceeded 2200 tons (Graham, 1952) and, although no estimates are available, large quantities of Georges Bank cod must also have been discarded.

Between 1930 and 1965, cod abundance on Georges Bank generally declined. CPUE indices of cod [available from a 'Boston-based haddock study fleet' of large otter-trawlers fishing Georges Bank (Hennemuth, MS 1969; Brown, MS 1971; Brown and Heyerdahl, MS 1972)], peaked in 1937, 1945 and 1961 but declined during 1938-40, 1946-52, and 1962-65 (Fig. 7). Apart from the early- to mid1940s, when offshore fishing effort was reduced due to World War II, fishing effort was relatively stable throughout the 35-year time period, fluctuating between 7000 and 13000 standard fishing days.

Despite a $50 \%$ decline in Georges Bank cod landings between 1930 and 1950 (Fig. 3), research effort on cod was quite limited during these two decades (Jensen, 1968). However, the research and sampling programs initially established in the early-1930s to study haddock were expanded in the 1940 s and 1950s to encompass other species, including cod (Rounsefell, 1948). These and suc- ceeding programs subsequently proved invaluable in providing the scientific foundation for research and management activities for cod under ICNAF and under the USA Magnuson Fishery Conservation and Management Act (MFCMA) enacted in 1976 (Fogarty et al., MS 1989). Through these initiatives, it finally became possible to relate changes in cod landings to changes in stock abundance and fishing effort (Sette, 1928; North American Council on Fishery Investigations, 1932).

ICNAF-Era Assessments (1965-76). Beginning in the early-1960s, comprehensive commercial fishery weighout, interview, and catch sampling systems were established and computerized at the Northeast Fisheries Center at Woods Hole, Massachusetts (Mayo, MS 1977; Burns et al., 1983). These developments, along with the implementation (in 1963) of a standardized research vessel bottom-trawl survey program (Grosslein, 1969; Clark, 1979; Azarovitz, 1981) provided a basis for conducting assessments to evaluate trends in landings, fishing effort, stock abundance and recruitment of cod on Georges Bank. A chronology of the Georges Bank cod assessments is provided in Table 3 , which highlights principal findings and conclusions.

The first formal assessment of cod in Subarea 5 was conducted in 1971 (Brown, MS 1971; ICNAF, 1971), 10 years after the Canadian and distantwater fleet fisheries for cod had developed on Georges Bank. Peak Canadian landings of cod occurred in 1965 and 1966, while foreign catches had peaked during 1965-69 (Table 1; Fig. 4). However, there was still great concern about the effects of the heightened fishing intensity on biomass levels and stock productivity. Based on analysis of trends in commercial effort, CPUE and research survey abundance indices, the 1971 assessment indicated that Maximum Sustainable Yield (MSY) was between 30000 and 40000 tons, and noted that annual landings of Subarea 5 cod had exceeded 40 000 tons since 1965 .

In 1972, a more complete assessment of the Georges Bank stock (Div. 5Z) indicated that cod abundance had remained stable between 1963-71 (Table 4, Fig. 8) and that the elevated catches during 1965-69 were primarily due to increased fishing effort (Brown and Heyerdahl, MS 1972; ICNAF, 1972). Results from a generalized production model suggested that MSY for Georges Bank cod was about 35000 tons, with effort at MSY estimated to be 30000 standard days fished. Fishing effort had exceeded this level during the mid-1960s but had declined to below 30000 days in 1970 and 1971. Based on trends in cod CPUE (from the 'Boston-based haddock study fleet'), average cod abundance during 1964-71 appeared to be lower than in the 1931-63 period (Brown and Heyerdahl, MS 1972). 

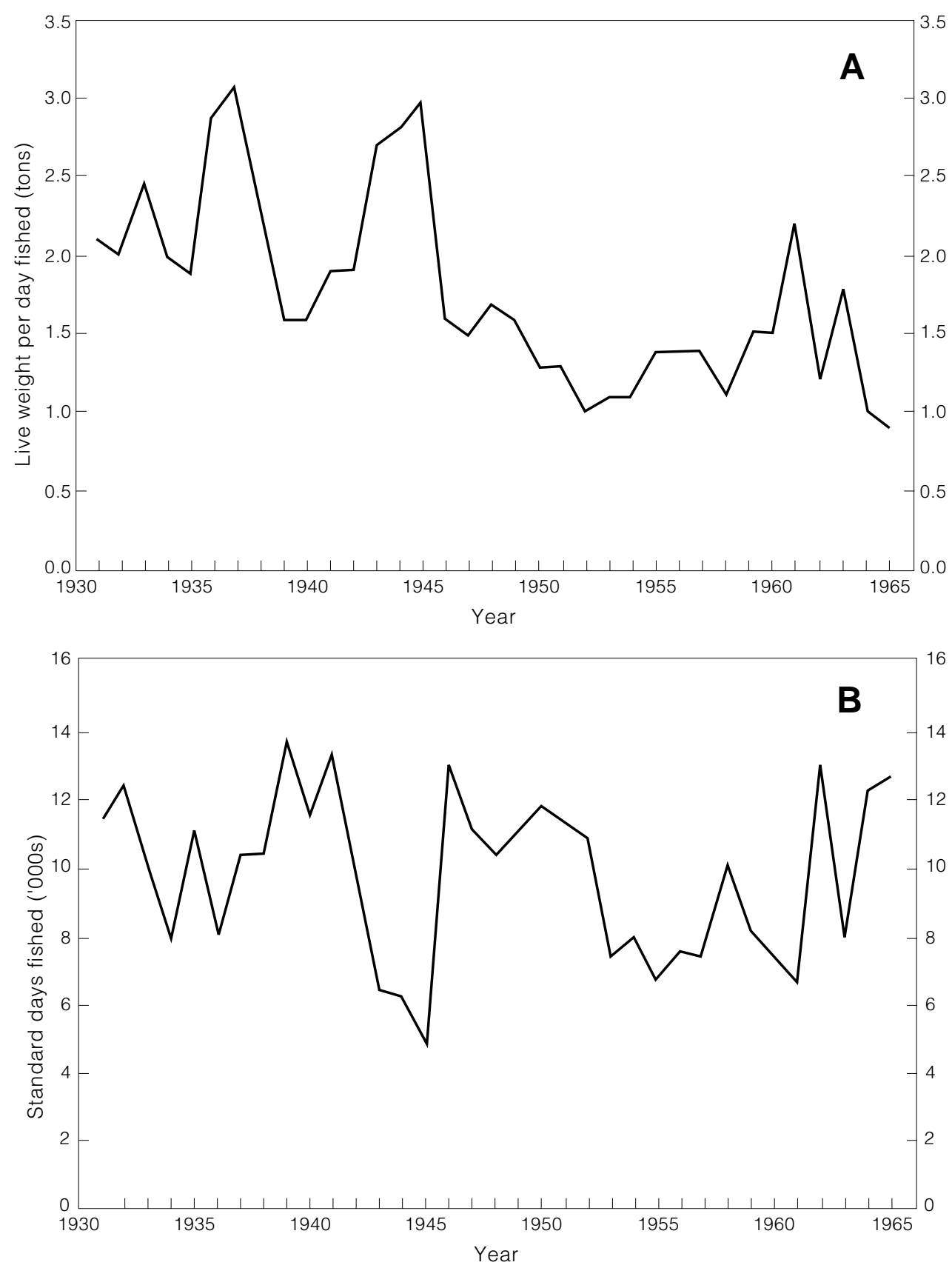

Fig. 7. (A) USA commercial catch per day fished of Georges Bank cod and (B) annual USA fishing effort for Georges Bank cod, 1931-65 (from Brown and Heyerdahl, MS 1972)

Although no new assessments were conducted from 1973 through 1975, ICNAF established a 35000 tons Total Allowable Catch (TAC) in 1973 for Div. $5 Z$ cod. This TAC corresponded to the estimated MSY level and was recommended on the basis that the stock seemed to be exploited at a reasonable level, and that the TAC would prevent a rapid expansion of effort on the stock (ICNAF, 1973).
Discouraging additional effort in the cod fishery was an important concern since Georges Bank haddock had already collapsed from overfishing. Equally, the magnitude and severity of the impacts caused by the high fishing effort in the 1960s on the total finfish biomass in Subareas 5 and 6 were beginning to be well-understood (Brown et al., 1976; Clark and Brown, 1977; 1979). 
TABLE 3. Chronology of Assessment conducted on Georges Bank cod (all assessments are by USA scientists unless indicated otherwise).

\begin{tabular}{|c|c|c|c|}
\hline Year & Aroa & Source & Results and Conclusions \\
\hline 1971 & SA 5 & $\begin{array}{l}\text { Brown, MS } 1971 \\
\text { ICNAF، } 1971\end{array}$ & $\begin{array}{l}\text { Catch and effort increased greatly since 1964; some CPUE indices have decreased through } \\
\text { 1970; research survey indices do not indicate any increases in stock size or recruitment: MSY is } \\
\text { probably between } 30000-40000 \text { tons; fishery is judged fully exploited at present and increases in } \\
\text { effort should be avoided until a more complete assessment is made. }\end{array}$ \\
\hline 1972 & Drv. $5 Z$ & $\begin{array}{l}\text { Brown and Heyerdahl, MS } 1972 \\
\text { Heyerdahl, MS } 1972 \\
\text { ICNAF, } 1972\end{array}$ & $\begin{array}{l}\text { Survey indices peaked in } 1963-64 \text {, declined to lowest levels in } 1965-66 \text {, and remained steady at } \\
\text { intermediate levels since 1967; USA CPUE indices have shown similar trends, but 1964-71 indices } \\
\text { are lower than 1931-63 mean; } F_{\max }=0.3 ; \text { MSY is about } 35000 \text { tons; effort at MSY is } 30000 \\
\text { standard days fished, effort in mid-60s exceeded this level. }\end{array}$ \\
\hline 1973 & Div. $\mathbf{5 Z}$ & ICNAF, 1973 & $\begin{array}{l}\text { The } 1973 \text { TAC for the stock was set at } 35000 \text { tons, considered to be the long-term MSY: the } \\
1972 \text { catch was about } 24000 \text { tons; No new evidence to change the TAC for } 1974 \text { from } 35000 \\
\text { tons; a new assessment should be carried out but presently the stock seems to be exploited at a } \\
\text { 'reasonable level' and the TAC should prevent rapid expansion of effort. }\end{array}$ \\
\hline 1974 & Div. $\mathbf{5 z}$ & ICNAF, 1974 & $\begin{array}{l}\text { No new assessment avalable; } 1973 \text { catch was } 28500 \text { tons, }<35000 \text { tons TAC (considered as } \\
\text { MSY); USA commercial LFs show an increase in recruitrnent (R) from } 1971 \text { cohort: survey pre- } \\
\text { recrutt indices suggest that commercial stock size will increase in } 1975 \text { and 1976; catches from } \\
\text { increased R will result in } F_{\text {MSY, so maintain } 35000 \text { tons TAC for } 1975 \text {. }}\end{array}$ \\
\hline 1975 & Div. $5 Z$ & ICNAF, 1975 & $\begin{array}{l}\text { No new assessment available; catches in } 1965-75 \text { averaged } 34300 \text { tons and has been }<30000 \\
\text { tons since 1970; survey indices indicate a stable population since } 1963 ; 1971 \text { cohort is strong } \\
\text { and subsequent cohorts are present but not as abundant; current } F=0.35>F_{\text {max }} \text {; updated CPUE } \\
\text { data give MSY of } 32500 \text { tons but no firm basis to change } 35000 \text { tons TAC for } 1986 \text {. }\end{array}$ \\
\hline 1976 & Div. $5 z$ & $\begin{array}{l}\text { Pentula and Gifford, } 1976 \\
\text { ICNAF, } 1976\end{array}$ & $\begin{array}{l}\text { Survey data indicate a stable abundance level since } 1963 \text { with good } \mathrm{R} \text { since } 1970 \text {; } 1975 \text { cohort } \\
\text { appears strong, equal to } 1971 \text { cohort; preliminary VPA indicates that } F \text { in late } 1960 \text { s was between } \\
0.55-065 \text {. If } \mathrm{R} \text { remains stable, catch at } F_{\max }(0.3) \text { would be } 24000 \text { tons; at } F_{01} \text {. catch would be } \\
15000 \text { tons; it is recommended that the TAC tor } 1977 \text { be set at } 15000 \text { tons. }\end{array}$ \\
\hline 1977 & Div. 5Z \& SA 6 & Serchuk ef al., MS 1977 & $\begin{array}{l}\text { VPA conducted using comm landings and estimated USA rec catches, 1960-76; survey } \\
\text { age/ength keys applied to commercial LFs in } 1960-76 \text { and } \| s \text {-at-8ge raised to include rec } \\
\text { catches. } F_{(3+)} \text { increased from } 0.35 \text { in } 1960-64 \text { to } 0.75 \text { in } 1971 \text {, and stablized at } 0.5-0.6 \text { from } 1973 \\
\text { to 1976; } S S B(3+) \text { declined by } 50 \% \text { between } 1965 \text { and } 1977 \text { (110 000 to } 65000 \text { tons). SSB and } \\
\text { total stock size would increase if } F \text { was reduced to } F_{\text {max }}(0.30) \text { or } F_{0},(0.18) \text {. }\end{array}$ \\
\hline 1978 & Div. $5 Z$ \& SA 6 & Serchuk et al. MS 1978 & $\begin{array}{l}\text { Stock sizes at age and Fs in } 1977 \text { and } 1978 \text { were projected from } 1960 \text { to } 1976 \text { VPA results using } \\
1977 \text { catch-at-age data and VPA/survey and F/effort relationships Due to considerable discards } \\
\text { of scrod in } 1977 \text { (irom the strong } 1975 \text { cohort), four discard scenarios were evaluated based on } \\
F 87_{(3+)}=0.45 \text {. To maintain stock size in } 1979 \text { at } 1978 \text { level, a total catch in } 1978 \text { (commercial and } \\
\text { recreational and discards) of between } 25000 \text { to } 28000 \text { tons would be required. }\end{array}$ \\
\hline 1979 & Div. $5 Z$ \& SA 6 & Serchuk et al., MS 1979 & $\begin{array}{l}\text { No VPA update; commercial landings in } 1978 \text { were } 35000 \text { tons, the highest since } 1969 \text { but } \\
\text { underestimate the catch due to high discarding and suspected unreported landings; recreational } \\
\text { landings in } 1977-78 \text { not known; the } 1978 \text { survey wt/tow indices were among the highest } \\
\text { observed due to strong } 1975 \text { cohort. Based on survey data, the cod stock is at a relatively high } \\
\text { level. }\end{array}$ \\
\hline 1980 & Div. $5 Z$ \& SA 6 & Serchuk of al., MS 1980 & $\begin{array}{l}\text { No VPA update; } 1979 \text { commercial landings were } 37000 \text { tons, highest since } 1969 \text { but under- } \\
\text { estimate the true catch: } 1979 \text { survey indices declined from } 1978 \text { but still among the highest } \\
\text { observed; } 1975 \text { cohort dominant in both stock and fishery; } 1979 \text { cohort better than average: } \\
\text { relative exploitation rates (total catch/survey weight index) stable since 1977, } 20 \% \text { lower than } \\
1971-76 \text { average. Overall, stock biomass remained at relatively high level in } 1979 \text {. }\end{array}$ \\
\hline 1981 & Div. $5 Z$ \& SA 6 & $\begin{array}{l}\text { Serchuk and Wood, MS } 1981 \\
\text { Serchuk et al., MS } 1981\end{array}$ & $\begin{array}{l}\text { No VPA update; } 1980 \text { comm landings were } 46000 \text { tons, highest since 1966; USA CPUE in 1977- } \\
80 \text { was highest in } 64-80 \text { time series; spring } 1980 \text { survey indices higher than in 1979, but autumn } \\
\text { survey indices lower; } 1978 \text { cohort above-average: relative exploitation rates have increased } \\
\text { since 1978; } 1980 \text { rate was highest since } 1970 \text { suggesting that F has increased to levels observed } \\
\text { during 1964-70 when stock declines ensued, continuation of } 46000 \text { tons catch levels will reduce } \\
\text { stock size. }\end{array}$ \\
\hline
\end{tabular}


TABLE 3. (Continued).

\begin{tabular}{|c|c|c|c|}
\hline Year & Area & Source & Results and Conclusions \\
\hline 1982 & Div. $5 Z$ \& SA 6 & Serchuk et al., MS 1982 & 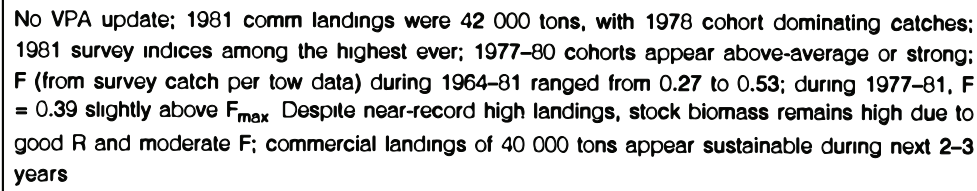 \\
\hline 1983 & Div. $5 Z \&$ SA 6 & $\begin{array}{l}\text { Hurley and O'Boyle, MS } 1983 \\
\text { (Canada) }\end{array}$ & 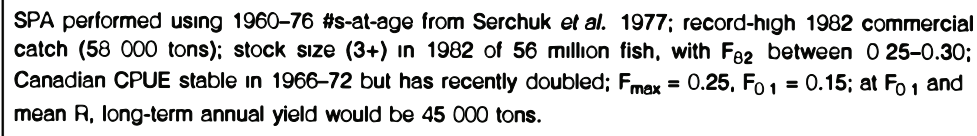 \\
\hline 1984 & Div. $5 Z$ \& SA 6 & $\begin{array}{l}\text { Hunt and Waiwood، MS } 1984 \\
\text { (Canada) }\end{array}$ & $\begin{array}{l}\text { No SPA update, } 1983 \text { comm landings were } 49000 \text { tons: Canadian CPUE in 1981-83 was } 2 x \\
\text { historical average; USA autumn survey indices declined to low levels in } 1982 \text { and 1983; } 1983 \\
\text { cohort seems above-average; } F_{83} \text { assumed to be } 0.40 \text { from spring survey data, if } 1984 \text { catch is } \\
45000 \text { tons, } F_{0} \text {, catch in } 1985 \text { would be about } 20000 \text { tons. }\end{array}$ \\
\hline 1985 & Div. $5 Z$ \& SA 6 & $\begin{array}{l}\text { Hunt and Waiwood, MS } 1985 \\
\text { (Canada) }\end{array}$ & $\begin{array}{l}\text { Revised SPA using comm catch-at-age data from } 1978 \text { to } 1984 ; 1984 \text { comm catch (39 000 tons) } \\
\text { lowest since 1980; USA CPUE, stable from } 1978 \text { to } 1983 \text {, declined sharply in } 1984 \text { as did } \\
\text { Canadian otter-trawl CPUE; } 1984 \text { survey indices were unchanged from low } 1983 \text { levels; SPA } \\
\text { Indicated } F_{(3+)} \text { increased from } 0.4 \text { in } 1978 \text { to } 0.6 \text { in } 1983 \text { and 1984; stock biomass (3+) has tallen } \\
40 \% \text { since } 1980 \text { and in the beginning of } 1985 \text { was only } 73000 \text { tons, the lowest in the series. }\end{array}$ \\
\hline \multirow[t]{2}{*}{1986} & Div. $5 Z$ \& SA 6 & $\begin{array}{l}\text { Serchuk and Wigley, MS } 1986 \\
\quad \text { NEFC, MS } 1986\end{array}$ & $\begin{array}{l}\text { Fevised VPA using comm catch-at-age data from } 1978 \text { to } 1985 \text {; } 1985 \text { comm catch ( } 37000 \text { tons) } \\
\text { lowest in } 7 \text { years; USA CPUE has declined since } 1982 \text {, with } 1985 \text { CPUE lowest ever; total fishung } \\
\text { effort in } 1985 \text { was a record-high; autumn } 1985 \text { survey indices were among lowest observed; } \\
\text { strong } 1980 \text { and } 1983 \text { cohorts in both catch and stock; } 1985 \text { cohort may be strong. Between } \\
1978-85, F \text { doubled }(0.40 \text { to } 0.82 \text { ), while SSB fell by } 50 \% \text { to a record-low ( } 96000 \text { to } 46000 \text { tons); } \\
F_{01}=0.16, F_{\text {max }}=0.28 ; \text { At mean } A \text {, equillbrium yield at } F_{01}=33000 \text { tons, at } F_{\text {max }}=35000 \text { tons, } \\
\text { All data indicate a marked decline in stock size; the stock appears to be growth overfished and } \\
\text { perhaps in danger of recruitment overfishing. }\end{array}$ \\
\hline & Div. $5 Z \&$ SA 6 & $\begin{array}{l}\text { Hunt and Gavaris, MS } 1986 \\
\quad \text { (Canada) }\end{array}$ & $\begin{array}{l}\text { SPA updated incorporating } 1985 \text { data; } 1983 \text { cohort comprised } 50 \% \text { of } 1985 \text { comm catch; } \\
\text { Canadian CPUE increased in } 1985 \text { from reduced 1983-84 values; SPA indicates } F_{\theta 5}=0.45 \text { and } F \\
\text { has declined slightly since } 1982\left(F_{\theta 2}=0.51\right) \text {; stock biomass }(3+) \text { declined from } 95000 \text {-tons in } \\
1980 \text { to a record-low } 62000 \text { lons in } 1985 ; F_{0.1} \text { yield for the stock is less than } 15000 \text { tons, which } \\
\text { is exceeded by the } 1985 \text { USA catch (27 000 lons), and improvement in stock status will require } \\
\text { bilateral management by the USA and Canada. }\end{array}$ \\
\hline 1987 & Div. $52 \&$ SA 6 & $\begin{array}{c}\text { Hunt, MS } 1987 \\
\text { (Canada) }\end{array}$ & $\begin{array}{l}\text { SPA updated incorporating } 1986 \text { data; } 1986 \text { comm catch ( } 26000 \text { tons) lowest since } 1976 \text {, and } \\
50 \% \text { of } 1982 \text { catch ( } 57 \text { C00 tons); USA CPUE declined in } 1986 \text { to a new record-low: Canadian } \\
\text { CPUE in } 1986 \text { was slightly less than in 1985; USA autumn survey indices have been stable and } \\
\text { low since } 1982 \text { but increased slightly in 1986; indices from Canadian surveys (begun in 1986) } \\
\text { declined in } 1987 ; \text { strong } 1985 \text { cohort evident in both USA and Canadian surveys; SPA indicates } \\
F_{B 5}=082 \text { and } F_{B 6}=0.70 \text { (highest in 78-86 series); stock biomass ( } 3+\text { ) in } 1985 \text { and } 1986 \text { was a } \\
\text { record-low } 34000 \text { tons; stock rebuilding will not be possible without a bilateral USA/Canada } \\
\text { management strategy to reduce } F \text {. }\end{array}$ \\
\hline 1988 & Div. $5 Z$ \& SA 6 & $\begin{array}{l}\text { Serchuk, MS } 1988 \\
\text { NEFC, MS } 1989\end{array}$ & 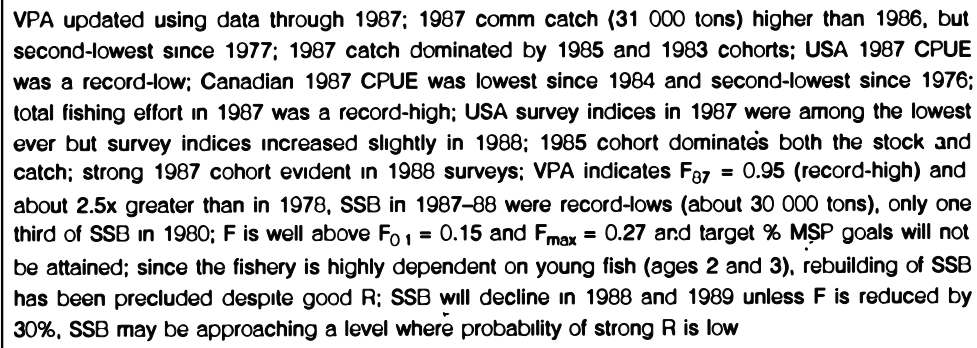 \\
\hline
\end{tabular}


TABLE 3. (Continued).

\begin{tabular}{|c|c|c|c|}
\hline Year & Area & Source & Results and Conclusione \\
\hline 1988 & Div. $5 Z$ \& SA 6 & $\begin{array}{l}\text { Hunt, MS } 1988 \\
\text { (Canada) }\end{array}$ & 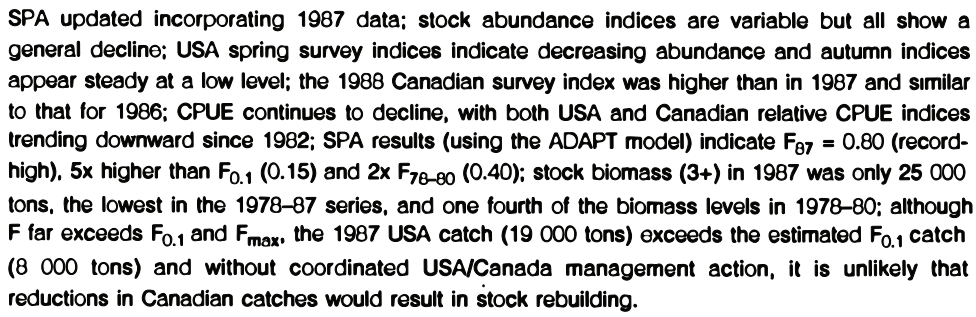 \\
\hline 1989 & Areas $5 \mathrm{Zj} 8 \mathrm{5Zm}$ & $\begin{array}{l}\text { Hunt, MS } 1989 \\
\text { (Canada) }\end{array}$ & $\begin{array}{l}1988 \text { comm catch (20 000 tons) in } 5 Z \text { J and } 5 Z \mathrm{~m} \text { was the highest since } 1983 ; 1985 \text { and } 1983 \\
\text { cohorts accounted for most of catch; standardized CPUE indices for both USA and Canada have } \\
\text { declined since 1978, with recent values among the lowest in the time series; } 1989 \text { Canadian and } \\
1988 \text { USA survey indices in 5Ze were higher than in 1987; strong } 1987 \text { and } 1985 \text { cohorts are } \\
\text { evident in both survey series; preliminary SPA indicated that F has been } 2-3 \times F_{0.1} \text { since } 1978 \text {. } \\
\text { Reduction of total catch by a factor of } 2 \text { in } 1990 \text { is required to approach } F_{01}=0.20 \text {. }\end{array}$ \\
\hline \multirow[t]{2}{*}{1990} & Div. $5 Z$ \& SA 6 & $\begin{array}{l}\text { Serchuk and Wigley, MS } 1990 \\
\text { NEFC, } 1990\end{array}$ & $\begin{array}{l}\text { VPA updated using data through 1989; } 1989 \text { comm catch ( } 33000 \text { tons) dominated by strong } 1985 \\
\text { cohort; fishing effort peaked in } 1989 \text { but declined slightly in } 1989 ; \text { USA survey indices increased In } \\
\text { both } 1988 \text { and } 1989, \text { and indicated strong R from } 1987 \text { and } 1988 \text { cohorts; VPA results (using } \\
\text { Laurec-Shepherd tuning) indicate } F \text { peaked at } 0.7 \text { in } 1985 \text { and has boen about } 0.5-0.6 \text { since } \\
1986 ; \text { SSB declined } 50 \% \text { between } 1980 \text { and } 1986 \text {, but has since increased to } 66000 \text { tons } \\
\text { (slightly below the } 1978-89 \text { average) due to strong } 1983,1985 \text { and } 1988 \text { cohorts; } F_{0.1}=0.15 \text {; } \\
F_{\max }=0.27 ; F_{\operatorname{med}}=0.47 \text {; calch and stock size projections for } 1990-92 \text { are critically dependent on } \\
\text { strength of } 1988 \text { cohort. }\end{array}$ \\
\hline & Areas $5 \mathrm{Zj} \& 5 \mathrm{Zm}$ & $\begin{array}{l}\text { Hunt, MS } 1990 \\
\text { (Canada) }\end{array}$ & $\begin{array}{l}1989 \text { comm catch ( } 14000 \text { tons) lowest since } 1986 \text { and dominated by } 1985 \text { and } 1987 \text { cohorts: } \\
\text { SPA (tuned using ADAPT) indicated the } 3+F_{89}=0.29 \text {, a record-low value mostly because of an } \\
\text { early closure of the Canadian trawl fishery; } 1990 \text { stock biomass }(3+) \text { was } 69000 \text { tons, well above } \\
1970-90 \text { mean ( } 49000 \text { tons); } F_{90} \text { is expected to be } 0.39 \text { and } F_{91} \text { will range between } 0.2-0.4 \text {, } \\
\text { depending on catch options }\left(F_{01}, 50 \% \text { rule in } 1991 \text {; catch } 91=\text { catch } 90 \text { ). }\right.\end{array}$ \\
\hline \multirow[t]{2}{*}{1991} & Div. $5 Z$ \& SA 6 & $\begin{array}{l}\text { Serchuk et al., MS } 1991 \\
\text { NEFC, MS } 1992\end{array}$ & 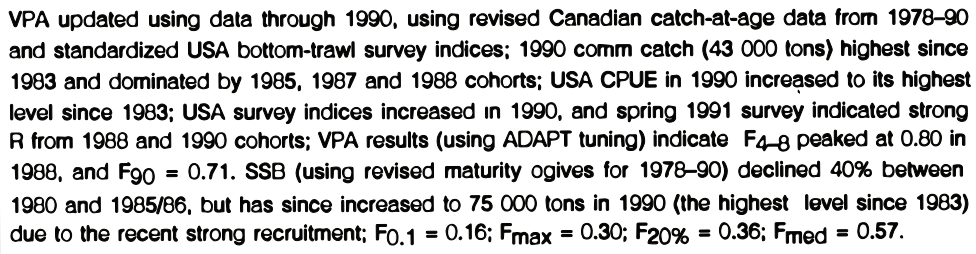 \\
\hline & Areas $5 \mathrm{Zj} \& 5 \mathrm{Zm}$ & $\begin{array}{l}\text { Hunt et al. MS } 1991 \\
\text { (Canada) }\end{array}$ & $\begin{array}{l}1990 \text { total comm catch ( } 21 \text { O00 tons) highest since } 1983 \text { and dominated by } 1985 \text { and } 1987 \\
\text { cohorts; SPA (tuned using ADAPT) indicated the } 3+F_{90}=0.40 \text { (about the same level as during } \\
1986-88 \text { ) and a stock blomass ( } 3+\text { ) at the beginning of } 1991 \text { of } 71000 \text { tons, well above } 1978-90 \\
\text { mean ( } 49 \text { O00 tons); } F_{91} \text { is expected to be } 0.42 \text { and } F_{92} \text { will be either } 0.30 \text { or } 0.46 \text {, depending on } \\
\text { catch options ( } 50 \% \text { rule in 1992; catch } 92 \text { = catch } 91 \text { ); Partitioning of total advised catch between } \\
\text { Canada and the USA is required if management objectives are to be achieved. }\end{array}$ \\
\hline
\end{tabular}

The 35000 tons TAC for Div. $5 Z$ cod was maintained during 1974-76, but annual catches never exceeded 27000 tons in these years (Table 1). In 1974 , the minimum cod-end mesh size in the Subarea 5 cod trawl fishery was increased to $130 \mathrm{~mm}$ (5.1 inches), and seasonal and area closures were introduced prohibiting large vessels (>44.2 m; 145 $\mathrm{ft}$ ) from demersal fishing within prescribed regions of Georges Bank. These latter restrictions were supplemental to the seasonal/area closures of haddock spawning grounds on Georges Bank which had been instituted annually since 1970. Apart from protecting haddock, closure of the haddock grounds was also expected to result in reduced catches of Georges Bank cod since both species were generally caught together in the Georges Bank otter trawl fishery (Serchuk and Wood, MS 1979).

The 1976 Georges Bank (Div. 5Z) cod assessment was the last one conducted under the aegis of ICNAF, but proved to be critically important since it served as the scientific basis for many of the management actions taken in 1977 under USA extended fisheries jurisdiction. While the 1976 assessment still indicated that cod abundance was stable, catch curve analysis of survey data indicated that during 
TABLE 4. Standardized stratified mean catch-pertow in numbers and weight $(\mathrm{kg})$ for Atlantic cod in NEFC offshore spring and autumn research vessel bottom trawl surveys on Georges Bank (Strata 13-25), 1963-90 a,b,c

\begin{tabular}{|c|c|c|c|c|}
\hline \multirow[b]{2}{*}{ Year } & \multicolumn{2}{|c|}{ Spring } & \multicolumn{2}{|c|}{ Autumn } \\
\hline & No./Tow & Wt./Tow & No./Tow & Wt./Tow \\
\hline 1963 & - & - & 4.37 & 17.8 \\
\hline 1964 & - & - & 2.98 & 11.6 \\
\hline 1965 & - & - & 4.25 & 11.7 \\
\hline 1966 & - & - & 4.81 & 8.1 \\
\hline 1967 & - & - & 10.38 & 13.6 \\
\hline 1968 & 4.72 & 12.6 & 3.30 & 8.6 \\
\hline 1969 & 4.64 & 17.8 & 2.20 & 8.0 \\
\hline 1970 & 4.34 & 15.6 & 5.07 & 12.5 \\
\hline 1971 & 3.39 & 14.2 & 3.19 & 9.9 \\
\hline 1972 & 8.97 & 19.0 & 13.09 & 23.0 \\
\hline 1973 & $18.68^{d}$ & $39.7^{d}$ & 12.28 & 30.8 \\
\hline 1974 & 14.75 & 36.4 & 3.49 & 8.2 \\
\hline 1975 & 6.89 & 26.0 & 6.41 & 14.1 \\
\hline 1976 & 7.06 & 18.6 & 10.44 & 17.7 \\
\hline 1977 & 6.30 & 15.4 & 5.45 & 12.5 \\
\hline 1978 & 12.31 & 31.2 & 8.59 & 23.3 \\
\hline 1979 & 5.16 & 16.9 & 5.95 & 16.5 \\
\hline 1980 & 7.75 & 24.9 & 2.91 & 6.7 \\
\hline 1981 & 10.44 & 26.1 & 9.04 & 19.0 \\
\hline 1982 & $8.20^{\mathrm{e}}$ & $15.4^{\mathrm{e}}$ & 3.71 & 6.9 \\
\hline 1983 & 7.70 & 24.0 & 3.64 & 6.5 \\
\hline 1984 & 4.08 & 15.4 & 4.75 & 10.3 \\
\hline 1985 & 6.94 & 21.5 & 2.43 & 3.5 \\
\hline 1986 & 5.04 & 16.7 & 3.12 & 4.7 \\
\hline 1987 & 3.26 & 10.3 & 2.33 & 4.4 \\
\hline 1988 & 5.86 & 13.5 & 3.11 & 5.8 \\
\hline 1989 & 4.80 & 10.8 & 4.78 & 4.6 \\
\hline 1990 & 4.74 & 11.6 & $3.62^{f}$ & $7.1^{f}$ \\
\hline 1991 & 4.39 & 9.0 & & \\
\hline
\end{tabular}

a During 1963-84 spring and autumn surveys, BMV oval doors were used; since 1985, Portuguese polyvalent doors have been used. Adjustments have been made to the 1963-84 catch-per-tow data to standardize to polyvalent door equivalents. Conversion coefficients of 1.56 (numbers) and 1.62 (weight) were used in the standardization (NEFC, MS 1991).

b R/V Delaware II was used in spring surveys during 1981-82 and 1989-91 and autumn surveys during 1977-81 and 198991 and, the R/V Albatross IV in all other years. Adjustments have been made to the R/V Delaware II catch-per-tow data to standardize these to R/V Albatross IV equivalents. Conversion coefficients of 0.79 (numbers) and 0.67 (weight) were used in the standardization (NEFC, MS 1991).

c Spring surveys during 1973-81 were accomplished with a ' 41 Yankee' trawl, in all other years with a '36 Yankee' trawl. No adjustments have been made to the catch-per-tow data for these gear differences.

d Excludes unusually high catch of $1894 \operatorname{cod}(2558 \mathrm{~kg})$ at Station 230 (Strata tow 20-4).

e Excludes unusually high catch of $1032 \mathrm{cod}(4096 \mathrm{~kg}$ ) at Station 323 (Strata tow 16-7).

f Excludes unusually high catch of $111 \mathrm{cod}(504 \mathrm{~kg})$ at Station 205 (Strata tow 23-4).
1970-74 (when commercial catches had averaged 26500 tons) fishing mortality (F) was 0.36, slightly above $F_{\max }=0.30$ (Penttila and Gifford, 1976).

Results from a preliminary VPA suggested that F values during the late-1960s (when Div. $5 Z$ catches averaged 41500 tons) ranged between $F=0.55-$ 0.65 (ICNAF, 1976). Yield-per-recruit analyses indicated that, given average recruitment, fishing at $F_{\text {max }}$ would generate a commercial catch of 24000 tons while fishing at $\mathrm{F}_{0.1}$ would result in a catch of 15000 tons. Although two very strong year-classes (1971 and 1975 cohorts) were evident in the stock (Table 5, Fig. 9), and despite apparent stability in both catches and stock abundance, the ICNAF Assessment Subcommittee recommended that the 1977 TAC for the Georges Bank cod stock be set at 15000 tons, corresponding to the $F_{0.1}$ catch. A 20000 tons TAC was subsequently established after USA industry advisors expressed concern that any lower TAC might produce adverse economic impacts.

In principle, the decision by ICNAF in 1976 to set TACs for 1977 on the basis of $F_{0.1}$ (Pinhorn and Halliday, 1990) was appropriate since many stocks had continued to decline when managed by ICNAF at $F_{\max }($ ICNAF, 1976, p. 76). However, the Georges Bank cod stock was not one of these. The Subcommittee recommendation (and the agreed-upon 20000 tons TAC) called for a catch in 1977 lower than any since 1961, at a time when recruitment of the strong 1975 year-class was expected to occur in the fishery. In hindsight, the seeds of pending turmoil had been sown. These would soon blossom, under USA extended jurisdiction, into a countless array of troublesome problems.

Management and Assessment Under Extended Jurisdiction (1977-90). In 1977, extended fisheries jurisdiction took effect in both the USA and Canada. Although the jurisdictional claims of both countries overlapped (thereby creating a disputed zone on Georges Bank), both countries (under an interim fisheries agreement) adopted the TACs (and TAC allocations) set by ICNAF for 1977, as well as the existing ICNAF minimum mesh size and haddock spawning area closure measures.

In the USA, under provisions of the MFCMA, the New England Fishery Management Council (NEFMC) had been established, and assumed management responsibility of cod, haddock and yellowtail flounder stocks in Subareas 5 and 6. The NEFMC developed a Fishery Management Plan for Atlantic Groundfish (FMP) to rebuild the 'seriously depleted' stocks of these species (NEFMC, 1977). Regulations were enacted on an emergency basis in March 


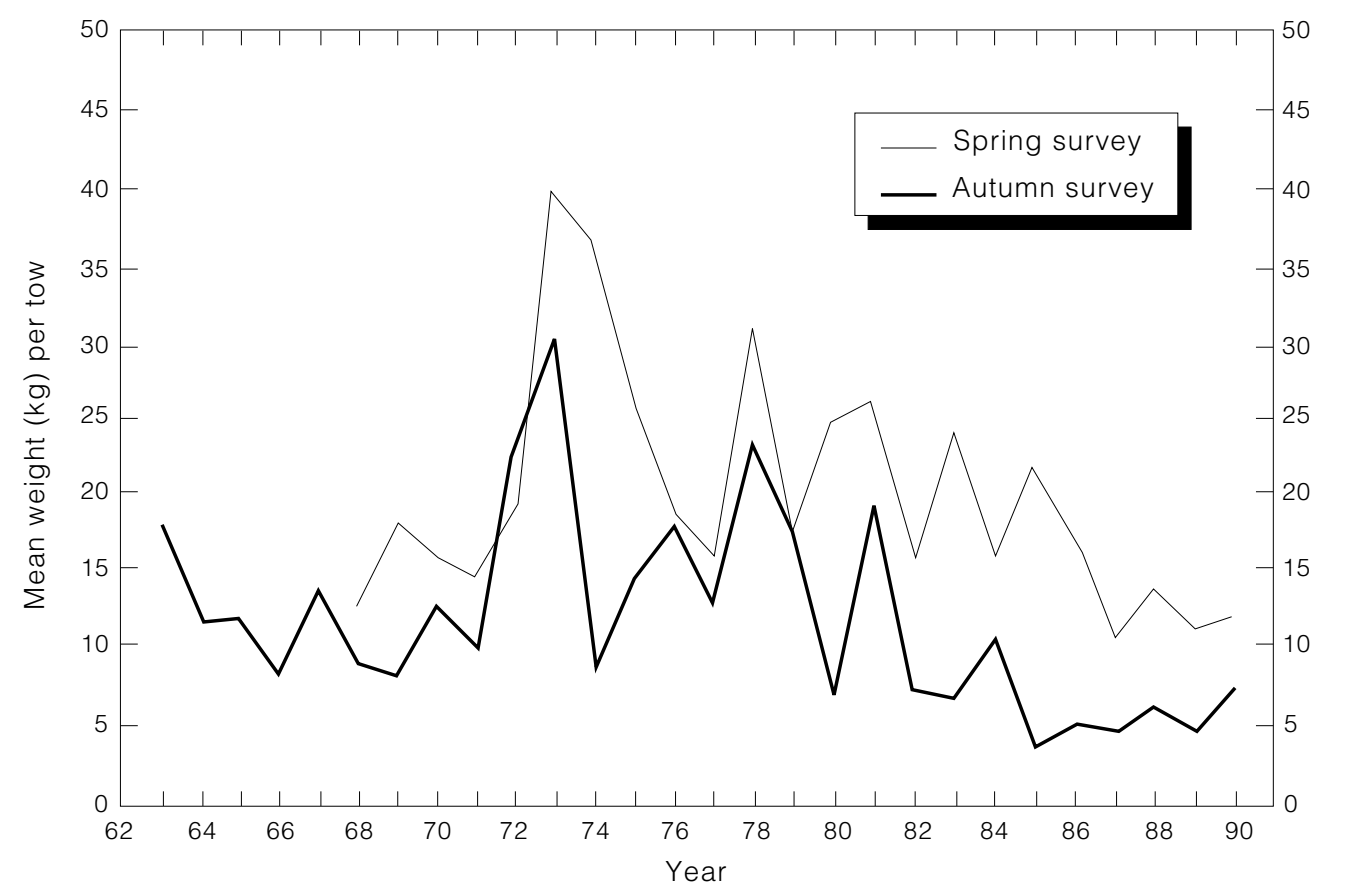

Fig. 8. Standardized stratified mean catch $(\mathrm{kg})$ per tow of cod in USA spring and autumn research vessel surveys on Georges Bank, 1963-90.

1977 that specified a minimum mesh size restriction (130 $\mathrm{mm})$, minimum fish sizes $(40.6 \mathrm{~cm}$ for cod), closed spawning areas (same as under ICNAF), and commercial and recreational fishery catch quotas (Optimum Yields, or 'OYs') for 1977 [for Georges Bank cod (now encompassing Div. $5 Z$ + Subarea 6): 20000 tons commercial; 10000 tons recreational]. The emergency regulations remained in effect until June 1977 when final regulations were enacted via implementation of the FMP itself. The final regulations deleted the recreational quotas but all other provisions pertaining to cod were retained.

The decision to manage the recreational cod fishery under the FMP (or at least account for the recreational catch in determining optimum yield) had been made in late-1976 when the Plan was being developed. At the time, the only data that existed were the catch estimates from the 1960, 1965, 1970 and 1974 recreational surveys (Table 2, Fig. 5). Although the accuracy of these estimates was unknown, these data were used to derive recreational landings by stock unit for each of the survey years, and to subsequently estimate recreational harvests in the years between surveys (NEFMC, 1977; Serchuk et al., MS 1977). The estimated recreational catches were incorporated into a surplus production analysis which indicated an overall MSY of 50000 tons for the Georges Bank cod stock (NEFMC, 1977) and also used in an initial VPA conducted in late-1977 (Serchuk et al., MS 1977).
Both analyses, however, were not very reliable due to the poor and limited quality of the recreational data. This was particularly true for the VPA and noted (along with other sources of uncertainty) in the assessment itself (Serchuk et al., MS 1977). In retrospect, the inclusion of the existing recreational data in the assessment analyses conducted during Plan development and during 1977-78 (Serchuk et al., MS 1978) was premature and overly ambitious. Although the recreational cod quota was eliminated in June 1977 because it was deemed arbitrary (i.e. set at the estimated 1974 catch level of 10000 tons of Georges Bank cod) and because of doubts as to whether it could be caught, there was little scientific basis for specifying such a quota in the first place.

In July 1977, a Reciprocal Fishing Agreement between the USA and Canada was signed which allocated 3350 tons of the 1977 Georges Bank cod quota to Canada (i.e. the allocation that would have occurred under ICNAF). As a result, the USA quota was reduced to 16650 tons (Pierce, 1982). By 22 August, $80 \%$ of the USA quota had been taken and the USA directed cod fishery was closed (the Canadian fishery for Georges Bank cod had closed on 9 August). Incidental fisheries continued, however, under various by-catch limitations. On 3 November, via a 45-day emergency amendment to the FMP, the 1977 Georges Bank quota was raised to 21650 tons. This allowed further incidental (and rather large) catches of cod but when the amendment 
TABLE 5. Standardized stratified mean catch-per-tow at age (numbers) of Atlantic cod in NEFC offshore spring and autumn bottom trawl surveys on Georges Bank, 1963-91a,b,c.

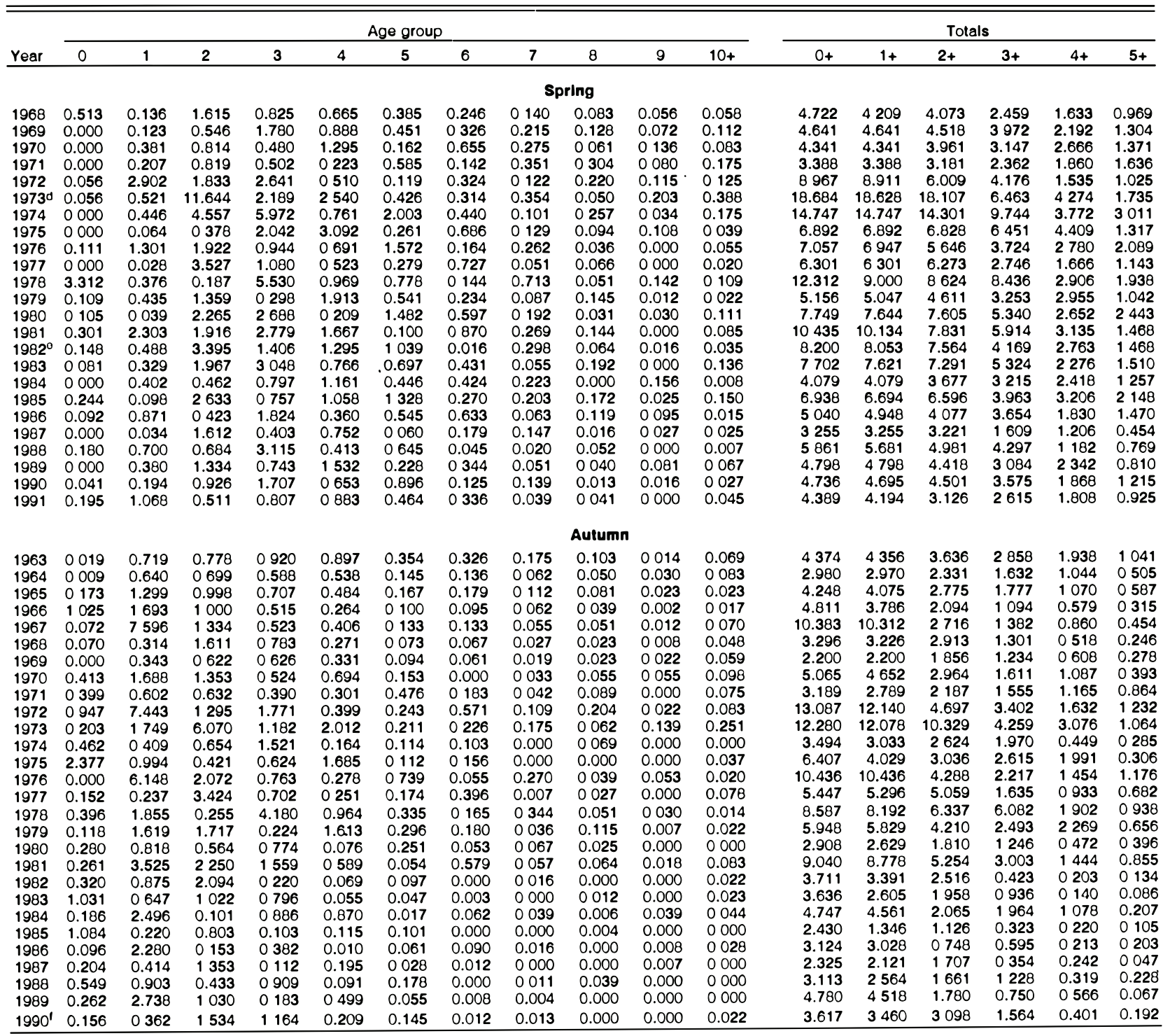

a Durino 1963-84 spring and autumn surveys, BMV oval doors were used, since 1985. Porluguese polyvalent doors have been used Adjusiments have been made to the 1963-84

calch-per-tow dala to standardize to polyvalent door equivalents Conversion coeficients of 156 (numbers) and 162 (weight) were used in the standardization (NEFC. MS 1991)

D R/V Delaware /I was used in spring surveys during 1981-82 and 1989-91 and the autumn surveys during 1977-91 and 1989-91 and, the R/V Albatross IVin all other years Adjusiments have been made to the $R / V$ Doleware ll calch-

in the standardization (NEFC. MS 1991)

c Spring surveys during 1973-81 were accomplished with a '41 Yanke日' Irawl, in all other years with a '36 Yankee' trawl No adjusimenis have been made to the catch-per-tow data for these gear diflerences

a Excludes unusually high caich of $1894 \operatorname{cod}(2558 \mathrm{~kg})$ at Siation 230 (Sirata tow 20-4)

- Excludes unusually high caich of $1032 \operatorname{cod}(4096 \mathrm{~kg}$ ) at Station 323 (Strata tow 16-7)

1 Excludes unusually high catch of $111 \operatorname{cod}(504 \mathrm{~kg})$ at Station 205 (Strata tow 23-4)

expired on 18 December, the entire USA groundfishery was closed, effective 24 December, for the remainder of the year.

Equally vexing problems concerning the management of the haddock and yellowtail flounder fisheries had to be faced by the NEFMC in 1977 and afterward (Anthony, 1990). Between 1977 and 1982, the Council was caught up with one problem after another - while struggling at the same time to (1) revise the management program on the basis of new assessment information, (2) resolve various allocation issues, (3) define management objectives, and (4) cope with increased dissension and dissatisfaction within the fishing industry regarding the supposed benefits of management actions. Nearly 50 

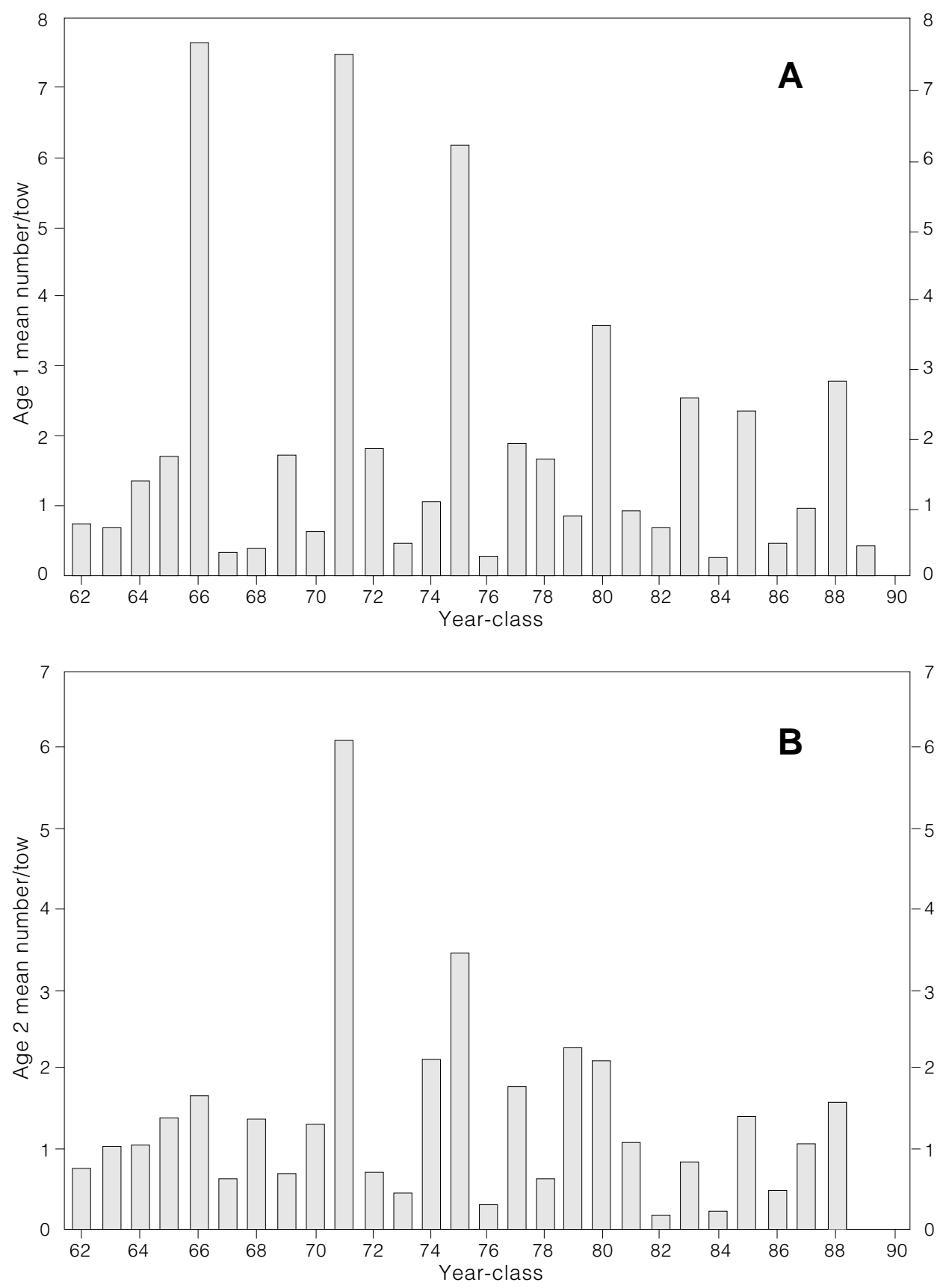

Fig. 9. (A) Relative year-class strength of Atlantic cod on Georges Bank at age 1 and (B) at age 2 based on standardized catch per tow indices from USA autumn bottom trawl surveys.

changes were made to the FMP management regulations during the 1977-82 period. For Georges Bank cod, management measures in these years varied but included annual and quarterly fishery catch quotas, Canadian and recreational catch allocations, weekly and/or trip landings restrictions (by vessel size class and gear type), fishery closures (both total and by vessel gear/size class), changes to the minimum mesh and minimum fish sizes, and data reporting requirements.

The 1978 Georges Bank OY, which had been set in April 1978 at 22000 tons for the USA commercial fishery, was increased to 26000 tons in July 1978 to allow 4000 tons for Canada. Management on a 'fishing year basis' (October-September) was insti- 
tuted in October 1978 to allow (among other things) more timely use of the USA bottom-trawl survey data in setting annual OYs (Clark et al., 1982). The 1978/ 79 OY for Georges Bank cod was initially set at 26000 tons but was revised upwards in July 1979 to 34960 tons (30 960 tons USA; 4000 tons for Canada) (Pierce, 1982). In both 1979/80 and 1980/ 81, the OY was set at 35000 tons (29 620 tons USA; 5380 tons Canada). All of the OYs, however, were exceeded as total commercial landings in the 197881 period ranged between 35000 and 48000 tons. Actual catches were probably much higher (especially during 1978 and 1979) since discarding and misreporting/underreporting of landings occurred as a consequence of many of the management restrictions (closures, trip limits, by-catch restrictions, etc).

The increased OYs during 1978-81 were predicated, in part, on assessment results which indicated that the Georges Bank stock had increased in size since 1975. The 1979-82 assessments (based largely on analyses of survey indices and USA commercial effort and CPUE data) all indicated that stock biomass was at a relatively high level, despite near-record high annual landings (Serchuk et al., MS 1979, MS 1980, MS 1981, MS 1982; Serchuk and Wood, MS 1981). Stock size had been maintained through a succession of above-average year-classes (1975, 1977, 1978 and 1980 cohorts) (Fig. 8 and 9), seemingly moderate fishing mortality rates (i.e. 0.30-0.40; Table 6), and proportional harvesting of the stock relative to its age/size distribution. However, there were indications that fishing effort had increased since 1977 and concern was raised that annual catches in excess of 40000 tons could well lead to stock size reductions (Serchuk and Wood, MS 1981). Also noted was the uncertain validity of the results derived from analysis of the commercial data due to discards and underreported catches.

During 1979, the NEFMC concluded that the existing management program was not working as envisaged, and that the management environment was unsatisfactory for making informed long-term management decisions. Industry support of the FMP had broken down due to the mis-match between Council actions and events in the fishery, as well as to the lack of adequate enforcement of management regulations. A wide credibility gap developed among fishermen, scientists and managers. The industry was puzzled by the stringency of catch controls at a time when apparently large numbers of cod (and haddock) were present in the sea. Scientists thought that managers understood that strict catch controls were necessary to use the good 1975 year-classes of cod and haddock for stock rebuilding (Anthony, 1990). Managers were caught in the cross-fire, and were also burdened by a slow administrative review process (Hennemuth and Rockwell, 1987) and a constant preoccupation with short-term FMP adjustments. In 1978, the NEFMC had begun work to develop a more comprehensive management program [the Atlantic Demersal Finfish Plan (ADF)] that would account for fishery interactions, given the multispecies nature of the demersal trawl fishery (Marchesseault et al., MS 1980). However, progress in developing the ADF Plan was slow and the NEFMC, realizing in 1979 that the current management system was not succeeding, decided to develop an 'Interim Fishery Management Plan' (Interim Plan) to replace the existing FMP and serve as a short-term bridge to the ADF Plan. The Interim Plan was implemented on 31 March 1982 and was expected to foster a renewed spirit of industry support through a less restrictive management program which eliminated quotas, trip limits, and vessel class catch allocations. A suite of indirect control measures on fishing mortality was enacted that included: creation of large mesh (130$\mathrm{mm}$ in 1982, $140 \mathrm{~mm}$ thereafter) and small mesh fishing areas, maintenance of the haddock seasonal spawning area closures, minimum fish size regulations (for cod, $43 \mathrm{~cm}$ for commercially-caught fish, $38 \mathrm{~cm}$ for fish caught by recreational fishing vessels), and record-keeping requirements for fish dealers and processors (NEFMC, 1981). The NEFMC believed that these measures would reduce the risk of recruitment overfishing, enhance fish spawning activity, and allow more accurate and reliable fishery data to be collected.

As the USA grappled with groundfish management during 1977-84, new initiatives were enacted under extended jurisdiction in Canada (Pinhorn and Halliday, 1990). In 1977, the Canadian Atlantic Fisheries Scientific Advisory Committee (CAFSAC) was formed to provide peer-reviewed scientific advice for the management of Canada's Atlantic fisheries. Assessments were vetted through CAFSAC and management advice provided in accordance with specific management objectives and strategies. Since Canada's long-term strategy was to control exploitation at moderate levels, annual advice on catch levels was generally given on the basis of $F_{0.1}$.

In 1977, as previously noted, Canada and the USA both adopted the TACs set by ICNAF for the Georges Bank groundfish stocks. Throughout 1977, fishing fleets from both countries had access to the other country's undisputed fishing zone under the Reciprocal Fisheries Agreement (which was intended to preserve the status quo based on traditional fishing patterns). Although this agreement expired at the end of 1977, it was provisionally continued into 1978 pending enactment of a new interim plan. However, on 2 June 1978, Canada asserted that the 
TABLE 6. Estimates of instantaneous total mortality $(Z)$ and fishing mortality (F) with instantaneous natural mortality (M) assumed to be 0.20 , for the Georges Bank cod stock for seven time-periods between 1964 and 1990, derived from NEFC offshore spring ${ }^{\mathrm{a}}$ and autumn ${ }^{\mathrm{b}}$ bottom trawl survey data.

\begin{tabular}{|c|c|c|c|c|c|c|}
\hline \multirow{2}{*}{$\begin{array}{l}\text { Time } \\
\text { period }\end{array}$} & \multicolumn{2}{|c|}{ Spring } & \multicolumn{2}{|c|}{ Autumn } & \multicolumn{2}{|c|}{ Geometric mean } \\
\hline & Z & $\mathrm{F}$ & Z & $\mathrm{F}$ & Z & $F$ \\
\hline 1964-67 & - & - & 0.73 & 0.53 & 0.73 & 0.53 \\
\hline $1968-72$ & 0.34 & 0.14 & 0.35 & 0.15 & 0.34 & 0.14 \\
\hline $1973-76$ & 0.70 & 0.50 & 0.56 & 0.36 & 0.63 & 0.43 \\
\hline $1977-81$ & 0.47 & 0.27 & 0.67 & 0.47 & 0.56 & 0.36 \\
\hline 1982-84 & 0.42 & 0.22 & 1.12 & 0.92 & 0.68 & 0.48 \\
\hline $1985-87$ & 0.84 & 0.64 & 1.45 & 1.25 & 1.10 & 0.90 \\
\hline 1988-90 & 0.60 & 0.40 & 0.60 & 0.40 & 0.60 & 0.40 \\
\hline
\end{tabular}

a Estimates derived from: In ( $\Sigma$ age $4+$ for year $i$ to $j / \Sigma$ age $5+$ for years $i+1$ to $j+1)$.

${ }^{b}$ Estimates derived from: $\ln \left(\sum\right.$ age $3+$ for years $i-1$ to $j-1 / \sum$ age $4+$ for years $i$ to $\left.j\right)$.

USA was not enforcing the terms of the Agreement and that USA fishing patterns had not been maintained (Christie, 1987). Subsequently, each country banned the other from fishing in its undisputed waters. This was the beginning of the end of cooperative management of transboundary fisheries resources between Canada and the USA. After June 1978, fish stocks on Georges Bank were managed separately and independently by each country, generally without reference to one another's actions. Although the USA and Canada signed two treaties in 1979 covering (1) submission of the maritime boundary dispute settlement to binding third-party settlement and (2) creation of an East Coast Fisheries Commission for the management and conservation of USA/Canada fisheries resources, the fisheries treaty was never ratified by the USA (due to opposition by the New England fishing industry) and thus never implemented. In October 1984, the maritime dispute between the USA and Canada was settled when the International Court of Justice (ICJ) delimited a maritime boundary between the two countries. Although jurisdictional claims were resolved by the ICJ boundary, the boundary had no biological basis with respect to the distribution of Georges Bank fish stocks. Consequently, the same stocks of fish (i.e. Georges Bank cod and haddock) continued to be managed one way in the USA and quite another way in Canada.

Although cooperative management of Georges Bank groundfish ended in 1978, cooperation between Canadian and USA scientists continued uninterrupted by any national differences in fishery policies. Scientific data were routinely exchanged and cooperative research projects planned and conducted. Since 1979, USA-Canada scientific discussions have been held (generally annually) to review assessment and fisheries issues, discuss databases and sampling programs, and collaborate on joint research of interest to both nations. Through these and other interactions (e.g. USA/Canada ageing workshops, exchange of scientists on research vessel cruises, informal consultations between colleagues, etc), information needed for assessment purposes has been made available to both parties. In this respect, the independent assessments of Georges Bank cod conducted by Canada and the USA have been based on common data.

The first Canadian assessment of Georges Bank cod was conducted in 1983 (Hurley and O'Boyle, MS 1983) and annual assessments have been performed ever since (Table 3). The 1985 assessment (Hunt and Waiwood, MS 1985) was the first to indicate that stock abundance had declined sharply after 1982. USA autumn survey indices in 1982-84 were among the lowest ever (Table 4, Fig. 8) and USA CPUE indices, stable during 1978-83, had fallen sharply in 1984 (Table 7, Fig. 10). Sequential population analysis (SPA) of combined USA/Canadian commercial catch-at-age data from 1978 to 1984 revealed that harvestable biomass (age $3+$ ) had declined by nearly 35\% between 1982 and 1985, with the 1985 stock size the lowest in the time series. Fishing mortality, which had averaged 0.44 during 1978-81, increased to $F=0.6\left(>2 x F_{\max }\right)$ during 1983-84. It finally seemed possible that the Georges Bank stock could be overfished.

The 1986 USA and Canadian assessments (Serchuk and Wigley, MS 1986; Hunt and Gavaris, MS 1986) corroborated the results of the 1985 assessment, and indicated that stock biomass had declined still further. The USA assessment indicated that $F$ increased from 0.48 in 1981 to 0.82 in 1985, while stock biomass $(3+)$ had declined from 90000 to 46000 tons. The autumn 1985 USA survey 
weight-per-tow index was a record-low (Fig. 8), as was the 1985 USA commercial CPUE (Fig. 10). USA fishing effort on cod had increased sharply in 1985 , due to redirection of fishing activity away from other groundfish stocks (i.e. haddock and yellowtail flounder which were in relatively poorer condition), and loss of access to fishing grounds as a result of the ICJ boundary decision. After the USA assessment had been vetted at the Fall 1986 Northeast Fisheries Center Stock Assessment Workshop (the peerreview forum, established in 1985, for USA Northwest Atlantic stock assessments), it was concluded that there had been a "significant decline in stock abundance" and that "the stock appears to be growth overfished and perhaps in danger of recruitment overfishing" (NEFC, MS 1986). The 1986 Canadian assessment noted that since "the $F_{0.1}$ yield for this stock is less than 15000 tons, which is exceeded by the current USA catch, any improvement in stock status will require bilateral management by the USA and Canada" (Hunt and Gavaris, MS 1986).

The assessments conducted in 1985-86 indicated that management of cod under the NEFMC Interim Plan had been ineffective. Although more accurate and reliable fisheries data were acquired under the Interim Plan, analysis of this information indicated that resource conditions had got worse, not better. This was true, not only for the Georges Bank cod stock, but for the entire demersal species complex (NEFC, MS 1987; Fig. 11). Commercial CPUE, both in the cod fishery and in the total Georges Bank trawl fishery, declined by $50 \%$ between 198286 and had reached record-low levels (Fig. 10 and 11).

In August 1985, the NEFMC completed the long awaited ADF Plan, now re-titled the Fishery Management Plan for the Northeast Multispecies Fishery (Multispecies Plan), and submitted it to the USA National Marine Fisheries Service (NMFS) for approval. The management unit covered by the plan encompassed the multispecies finfish fishery that operated from eastern Maine through Southern New England, including all commercial and recreational harvesting sectors in New England (NEFMC, MS 1985). Rather than dealing with just cod, haddock and yellowtail flounder, the Multispecies Plan intended to address all species in the demersal finfish complex in New England waters including cod, haddock, yellowtail flounder, pollock, redfish, white hake, American plaice, winter flounder, witch flounder and windowpane flounder. The basic conservation goal of the Plan was:

"to prevent stocks from reaching minimum abundance levels, defined as those levels below which there is an unacceptably high risk of recruitment failure".
The objective of the Plan was:

"to control fishing mortality on juveniles (primarily) and on adults (secondarily) of selected finfish stocks within the management unit for the purpose of maintaining sufficient spawning potential so that year-classes replace themselves in the stock on long-term average basis; and to similarly reduce fishing mortality for the purpose of rebuilding those stocks where it has been demonstrated that the spawning potential of the stock is insufficient to maintain a viable fishery resource; and further to promote the collection of data and information on the nature, behavior and activity of the multi-species fishery, and on the effectiveness of the management program" (NEFMC, 1985, p. 6.1).

Similar to the Interim Plan, the Multispecies Plan contained no management measures to directly control fishing mortality (i.e catch or effort limitations). Indirect controls were specified which included regulated mesh areas, minimum cod-end mesh size (140 $\mathrm{mm}$ when fishing in the large mesh area), minimum fish sizes (for cod: $43 \mathrm{~cm}$ during the first year of the plan, $48 \mathrm{~cm}$ thereafter), haddock and yellowtail flounder area closures, and seasonal/ area and by-catch restrictions governing the 'exempted' (small mesh) fisheries. For the major stocks within the Plan management unit, minimum levels of spawning potential were identified which were required for long-term biological productivity. These were based on analysis of spawning stock biomass per recruit (SSB/R), expressed as a percentage of maximum spawning potential (\% MSP) - since maximum SSB/R is obtained under conditions of no fishing mortality (Gabriel et al., 1989). For Georges Bank cod, the objective was to control fishing mortality to achieve 20\% MSP (NEFMC, 1985).

The Plan also established a Technical Monitoring Group (TMG) to monitor the multispecies fishery and report, at least annually, on the status of the resources and the operation of the fishery in relation to attainment of the conservation objective of the Plan.

The Multispecies Plan was initially rejected by the NMFS but was resubmitted in April 1986 and conditionally approved and implemented (for a 1year period) on 19 September 1986. During the first year, the NEFMC was to address the serious concern that the Plan allowed an unacceptably high level of juvenile mortality which threatened the spawning potential of the strong 1985 year-classes of Georges Bank cod and haddock. Actions to protect these cohorts were considered critical since recent assessments had shown that both stocks had markedly declined while the Plan was being developed. 
TABLE 7. USA commercial landings ( $L)^{\mathrm{a}}$, days fished $(\mathrm{DF})^{\mathrm{b}}$, and landings per day fished (L/DF), by vessel tonnage class (Class 2: 5-50 GRT; Class 3: 51-150 GRT: Class 4: 151-500 GRT), of Atlantic cod for otter trawl trips catching cod from Georges Bank (NAFO Subdivision 5Ze), 1965-90. Data are also provided for otter trawl trips in which cod comprised $50 \%$ or more of the total trip catch, by weight ("directed trips")

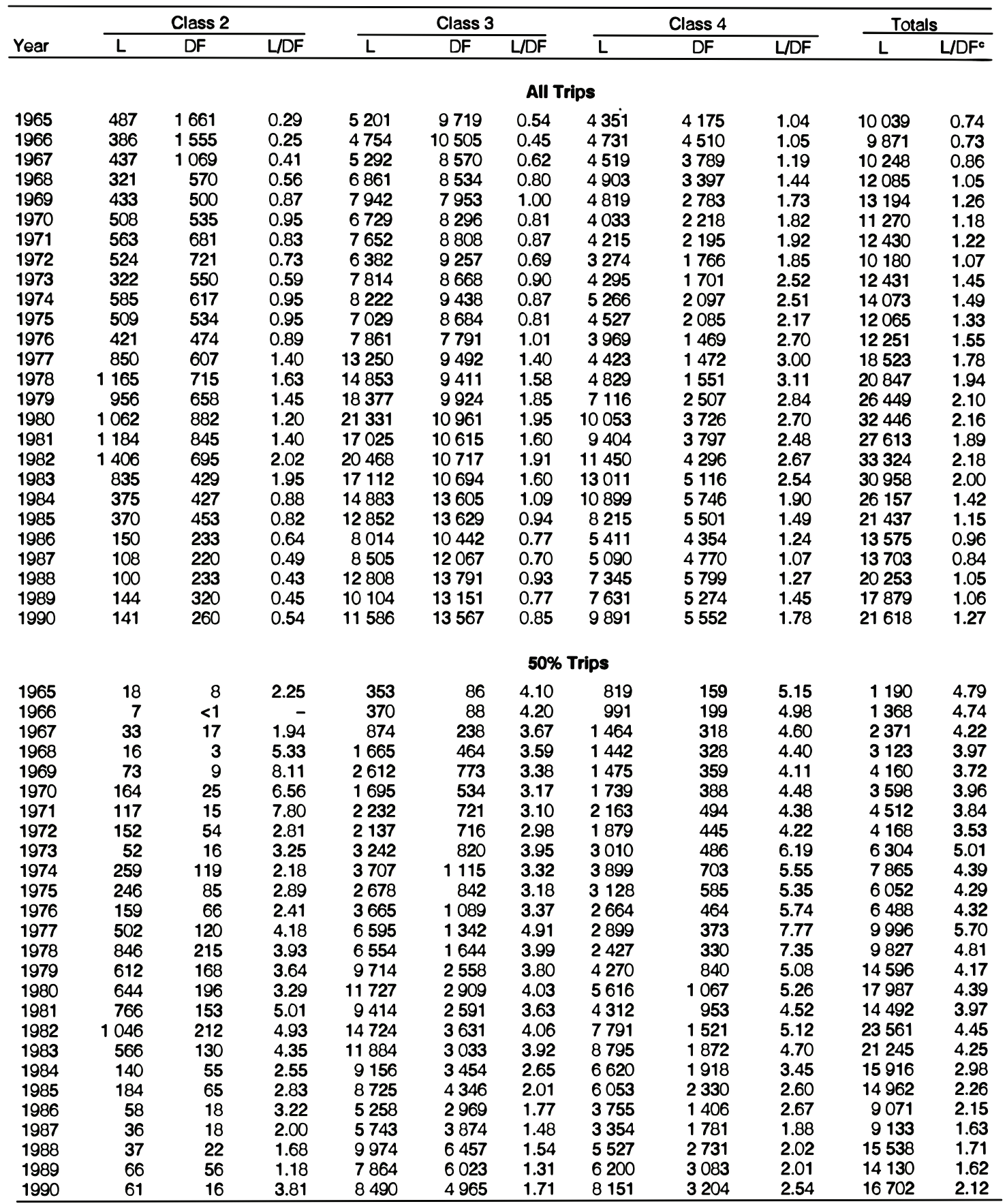

- In tons, live weight.

Days fished with trawl on bottom; derived by dividing hours fished with trawl on bottom by 24.

c Total L/DF was derived by weighting individual tonnage class L/DF values by the percentage of total landings accounted for by each vessel class and summing over the three vessel class categories. 


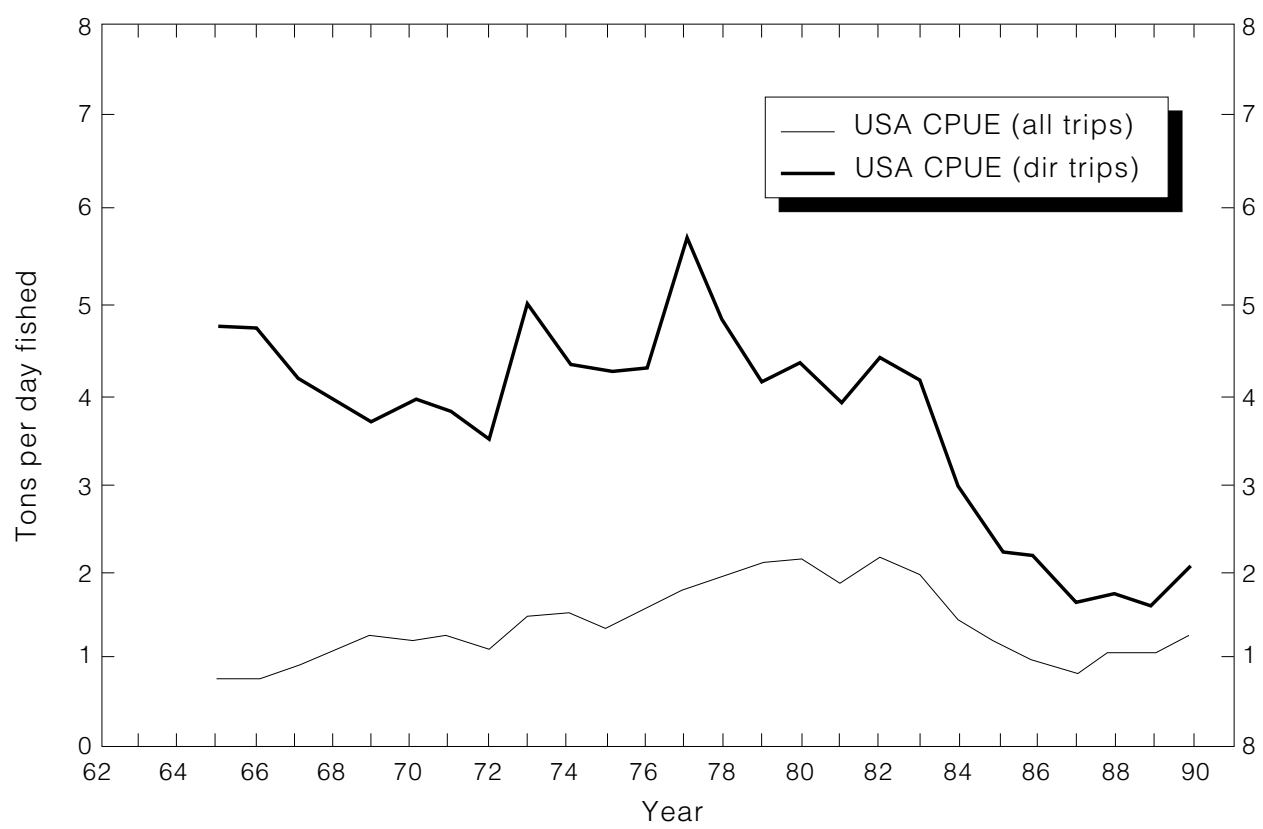

Fig. 10. Trends in USA commercial catch (tons) per day fished of Georges Bank cod. Data are based on all otter trawl trips in which cod were caught ('All Trips') and for otter trawl trips in which cod comprised $50 \%$ or more of the trip catch by weight ('Directed Trips').

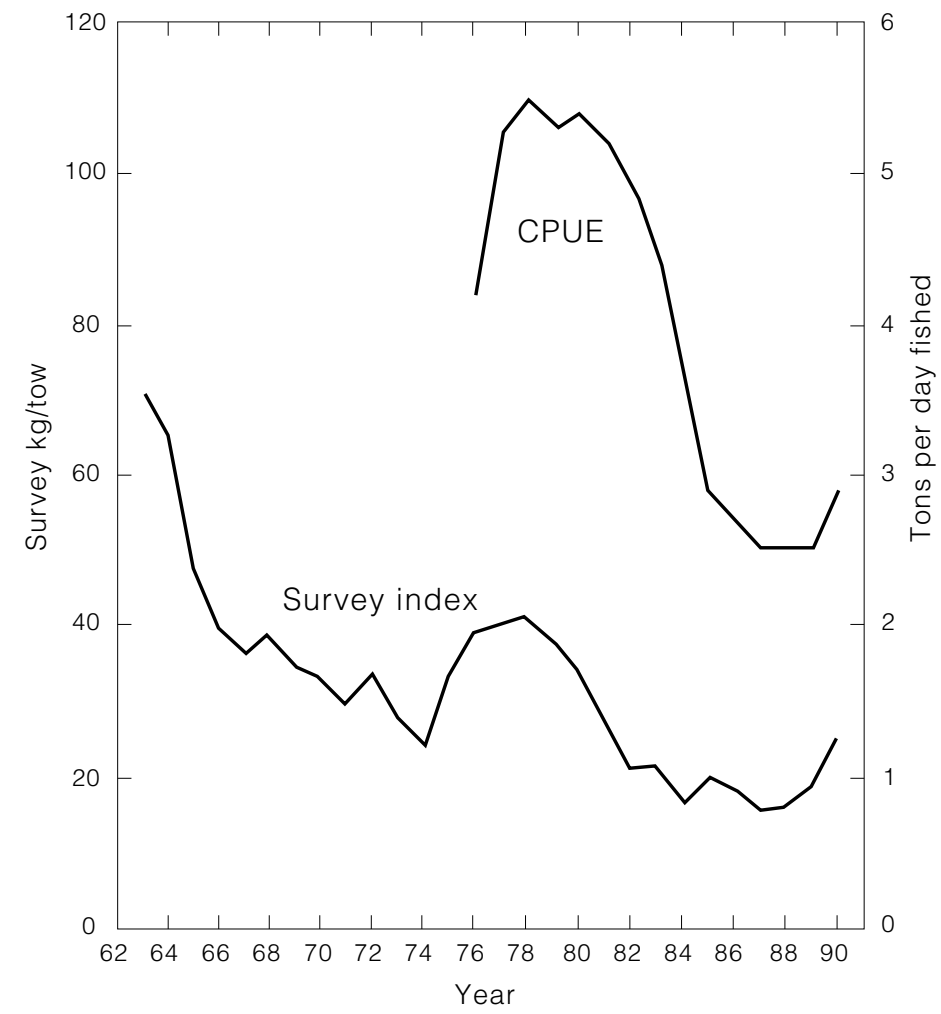

Fig. 11. Indices of abundance of principal groundfish and flounders off the New England coast from USA autumn bottom trawl surveys, and from USA commercial catch per unit of effort, 1963-90. 
On 1 October 1987, Amendment \#1 to the Multispecies Plan was approved and implemented. The Amendment was deemed to have appropriately addressed the deficiencies identified in 1986. However, most of the changes made were minor ones to the already existing measures. No new indirect (or direct) controls on fishing mortality were included in the Amendment (Anthony, 1990).

The 1987 and 1988 assessments (Hunt, MS 1987; MS 1988; Serchuk, MS 1988) indicated that the condition of the Georges Bank cod stock was still deteriorating. Spawning stock biomass in 1987 was the lowest in the VPA/SPA time series while fishing mortality had increased to a new recordhigh. Fishing mortality was greatly in excess of $F_{\max }$, and far beyond that corresponding to the 20\% MSP level. Because the fishery continued to be highly dependent on young fish (ages 2 and 3 ), rebuilding of the spawning stock had been precluded despite good recruitment. Concern was raised that the SSB was approaching a level where the probability of good recruitment might be low (NEFC, MS 1989). Significant reductions in fishing mortality were required if the stock was to be rebuilt.

In June 1988, the TMG submitted its initial evaluation to the NEFMC on the effectiveness of the Multispecies Plan (TMG, 1988). The TMG noted that: (1) almost all of the stocks covered under the Plan were at record-low levels of abundance, (2) most of the management measures in the Plan were either marginally effective or ineffective, (3) Plan regulations were difficult to enforce, unlikely to be enforced, or easy to circumvent, (4) incentives for compliance with the Plan did not exist, and (5) the difference in USA and Canadian management approaches (and regulations) were incompatible with achieving Plan objectives for the Georges Bank groundfish stocks. The TMG concluded that the overall management system (involving those who had created, administered, enforced, and been managed by the Plan) had not been very effective and appeared inadequate for dealing with resource maintenance and rebuilding needs (TMG, 1988). A series of recommendations for strengthening the Plan and management measures were provided by the TMG. With regard to achievement of \% MSP targets, it was recommended that, "the enforceability and design of management measures for controlling fishing mortality using catch, effort, or area controls should be explored in order to meet plan objectives" (TMG, 1988).

A similar evaluation of the lack of effectiveness of the Multispecies Plan in preventing overfishing and resource declines was rendered by the Massachusetts Offshore Groundfish Task Force in late 1990 (MOGTF, 1990). To achieve recovery of the groundfish stocks to pre-1960 levels, the Task Force recommended that: (1) direct controls be placed on fishing mortality, (2) wasteful fishing mortality (discarding) be reduced, (3) compliance with regulations be improved, (4) the biological basis for management be strengthened, (5) catch allocations be forthrightly addressed, (6) state regulations must support federal regulations, and (7) management council members be required to have a strong conservation ethic.

Canada also recognized that management of Georges Bank cod had become problematical. In both 1987 and 1988, CAFSAC noted that the Canadian fishery had also become heavily reliant on incoming year-classes and that stock rebuilding would not be possible "... until coordinated management action by Canada and the USA reduces the level of fishing mortality" (CAFSAC, MS 1987; MS 1988).

In July 1989, the Canadian Minister of Fisheries and Oceans commissioned a task force to develop an action plan to deal with problems of the ScotiaFundy groundfish industry and develop recommendations leading to long-term stability and prosperity in the groundfish industry. In December 1989, the Scotia-Fundy Groundfish Task Force issued its report (Haché, 1989) and noted that: (1) Canadian and USA approaches to fisheries management significantly differed, (2) each country had pursued management strategies without regard for the impact of the other country's actions, and (3) that since 1978, cod catches on Georges Bank had generated fishing mortality levels two or three times the target. The Task Force concluded that this situation was "not very satisfactory to orderly harvesting or stock conservation" and recommended that "discussions be pursued with the U.S. to develop compatible fishing approaches on Georges Bank including measures to ensure compliance, (although) reciprocal access was not to be considered" (Haché, 1989).

Although an agreement has subsequently been reached between the two countries on more effective enforcement of the ICJ boundary on Georges Bank, the issue of compatible fishing approaches has yet to be resolved. Canada established new management units in 1989 for Georges Bank cod and haddock, which geographically encompass all of the Canadian sector of Georges Bank (although a portion of these units still extend into the USA zone). Since 1989, Canadian assessments have been focused, almost exclusively, on the status of cod in these new units (Hunt, MS 1989; MS 1990; Hunt et al., MS 1991).

In the USA, the Multispecies Plan is still operative and has been amended three additional times 
since October1987. Although the most recent Plan Amendment \#4 (in 1991) acknowledged that many stocks covered by the Plan were being overfished (i.e. the \% MSP targets were not being met), the current Plan still lacks explicit rebuilding strategies for any of the stocks. This seems unfortunate since the 1990 and 1991 USA cod assessments (Serchuk and Wigley, MS 1990; Serchuk et al., MS 1991; NEFC, MS 1992) suggest that, due to good recruitment from the 1985, 1987, 1988 and 1990 yearclasses, the Georges Bank cod stock has started to recover (Table 8, Fig. 12).

However, the tides of management are changing. In July 1991, a legislative bill was introduced to the USA Congress to amend the MFCMA to provide for the restoration of New England groundfish stocks ('New England Groundfish Restoration Act of 1991'). Under this Act, a direct action plan would be established to double the spawning biomass of groundfish stocks within a 5-year period and negotiations
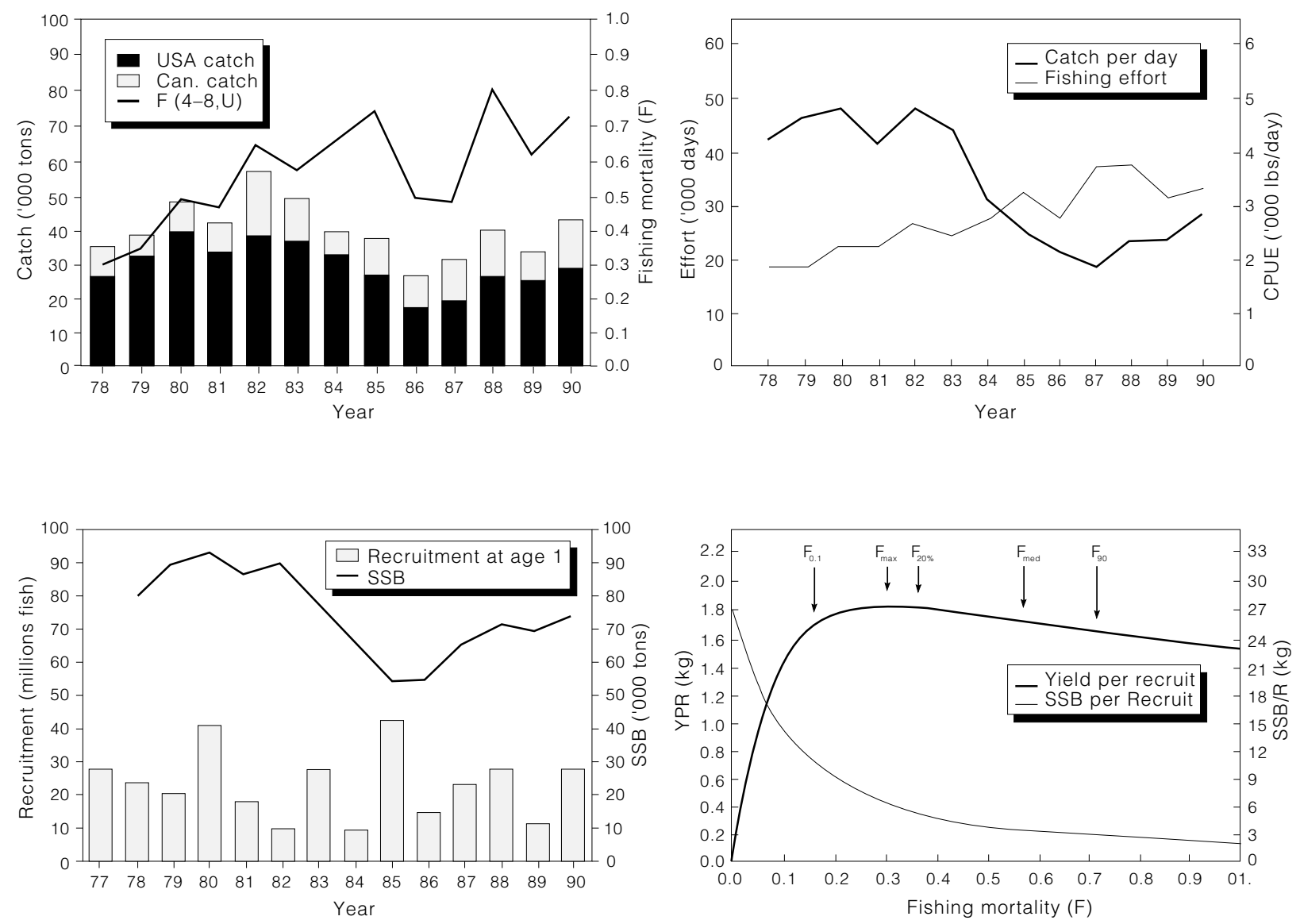

Fig.12. Stock assessment summary diagrams for Georges Bank cod from the 1991 USA assessment (from Serchuk et al., MS 1991; NEFC, MS 1992). would be initiated with Canada to improve the conservation of transboundary stocks. As well, enforcement of management regulations would be strengthened and innovative methods for reducing USA fishing effort (i.e. a vessel buyback program) would be authorized.

In August 1991, as a result of legal action brought against the NMFS for failure to prevent overfishing of groundfish stocks (i.e. violation of the MFCMA which requires that 'conservation and management degree was signed that required implementation (by 1 November 1992) of a new management plan designed to rebuild stocks of cod and yellowtail flounder within 5 years, and haddock within 10 years.

There is a growing resolve among managers, administrators, scientists and the fishing industry that fishing mortality must be reduced to improve the health of the stocks. measures shall prevent overfishing'), a consent 
TABLE 8. Estimates of fishing mortality (F), stock size (thousands of fish) and mean stock biomass (tons) derived from Virtual Population Analysis for the Georges Bank cod stock (NAFO Div. $5 Z$ and Area 6, 1978-90.

\begin{tabular}{|c|c|c|c|c|c|c|c|c|c|c|c|c|c|c|}
\hline \multirow[b]{2}{*}{ Age } & \multicolumn{14}{|c|}{ Year } \\
\hline & 1978 & 1979 & 1980 & 1981 & 1982 & 1983 & 1984 & 1985 & 1986 & 1987 & 1988 & 1989 & 1990 & 1991 \\
\hline $\begin{array}{c}1 \\
2 \\
3 \\
4 \\
5 \\
6 \\
7 \\
8 \\
9 \\
10+\end{array}$ & $\begin{array}{l}0.0001 \\
0.1073 \\
0.4086 \\
03861 \\
0.3838 \\
01379 \\
0.3091 \\
14849 \\
03605 \\
03605\end{array}$ & $\begin{array}{l}0.0016 \\
0.1019 \\
0.3811 \\
0.4902 \\
0.3608 \\
03789 \\
0.1122 \\
0.3921 \\
04384 \\
0.4384\end{array}$ & $\begin{array}{l}0.0049 \\
02448 \\
0.4845 \\
0.3780 \\
04561 \\
0.6370 \\
0.7911 \\
0.1789 \\
0.4895 \\
0.4895\end{array}$ & $\begin{array}{l}0.0007 \\
0.2437 \\
0.4757 \\
0.3885 \\
0.3061 \\
0.5621 \\
0.5476 \\
05227 \\
0.4425 \\
0.4425\end{array}$ & $\begin{array}{l}0.0212 \\
03540 \\
0.5144 \\
0.6758 \\
0.6361 \\
0.7405 \\
0.5816 \\
06067 \\
06617 \\
06617\end{array}$ & $\begin{array}{l}0.0126 \\
0.4134 \\
0.6120 \\
0.7500 \\
05913 \\
0.5471 \\
0.6032 \\
0.4102 \\
0.6510 \\
0.6510\end{array}$ & $\begin{array}{c}\text { Flshing M } \\
0.0032 \\
0.2070 \\
0.6918 \\
0.5562 \\
0.6286 \\
0.6572 \\
0.7443 \\
0.6319 \\
0.5990 \\
0.5990\end{array}$ & $\begin{array}{l}\text { rtallty } \\
0.0177 \\
0.3780 \\
0.7448 \\
06671 \\
0.7205 \\
0.7427 \\
0.6532 \\
0.9119 \\
07209 \\
0.7209\end{array}$ & $\begin{array}{l}0.0040 \\
0.2425 \\
0.5096 \\
05810 \\
0.5218 \\
0.5600 \\
0.3342 \\
0.4649 \\
0.5466 \\
05466\end{array}$ & $\begin{array}{l}0.0020 \\
0.2665 \\
0.4392 \\
0.4724 \\
0.4108 \\
0.5786 \\
0.5022 \\
0.4324 \\
0.4805 \\
04805\end{array}$ & $\begin{array}{l}00005 \\
0.1638 \\
05114 \\
06633 \\
0.7352 \\
0.7823 \\
0.9452 \\
0.8707 \\
07430 \\
0.7430\end{array}$ & $\begin{array}{l}0.0000 \\
0.1290 \\
0.5155 \\
0.5488 \\
0.4716 \\
0.6526 \\
0.6676 \\
0.7200 \\
0.5630 \\
0.5630\end{array}$ & $\begin{array}{l}0.0007 \\
0.2761 \\
0.5210 \\
0.7564 \\
0.6668 \\
0.7116 \\
0.7116 \\
0.7116 \\
0.7116 \\
0.7116\end{array}$ & \\
\hline $\begin{array}{l}F(4-8, u) \\
F(4-8, w)\end{array}$ & $\begin{array}{l}05404 \\
0.3621\end{array}$ & $\begin{array}{l}03468 \\
04375\end{array}$ & $\begin{array}{l}0.4882 \\
0.4921\end{array}$ & $\begin{array}{l}0.4654 \\
0.4413\end{array}$ & $\begin{array}{l}0.6481 \\
06509\end{array}$ & $\begin{array}{l}0.5804 \\
06459\end{array}$ & $\begin{array}{l}0.6437 \\
0.5913\end{array}$ & $\begin{array}{l}0.7391 \\
0.7083\end{array}$ & $\begin{array}{l}0.4924 \\
0.5409\end{array}$ & $\begin{array}{l}0.4793 \\
04753\end{array}$ & $\begin{array}{l}0.7993 \\
07306\end{array}$ & $\begin{array}{l}06121 \\
0.5557\end{array}$ & $\begin{array}{l}0.7116 \\
0.7062\end{array}$ & \\
\hline $\begin{array}{c}1 \\
2 \\
3 \\
4 \\
5 \\
6 \\
7 \\
8 \\
9 \\
10+\end{array}$ & $\begin{array}{r}27709 \\
4268 \\
25527 \\
7947 \\
2878 \\
1124 \\
1434 \\
67 \\
146 \\
54\end{array}$ & $\begin{array}{r}23520 \\
22685 \\
3139 \\
13889 \\
4422 \\
1605 \\
802 \\
862 \\
12 \\
148\end{array}$ & $\begin{array}{r}20102 \\
19226 \\
16773 \\
1755 \\
6965 \\
2524 \\
900 \\
587 \\
477 \\
28\end{array}$ & $\begin{array}{r}41406 \\
16378 \\
12323 \\
8459 \\
985 \\
3614 \\
1093 \\
334 \\
402 \\
190\end{array}$ & $\begin{array}{r}17454 \\
33876 \\
10509 \\
6270 \\
4696 \\
594 \\
1687 \\
518 \\
162 \\
187\end{array}$ & $\begin{array}{r}9553 \\
13990 \\
19467 \\
5144 \\
2612 \\
2035 \\
232 \\
772 \\
231 \\
148\end{array}$ & $\begin{array}{c}\text { Stock } \\
27647 \\
7724 \\
7576 \\
8642 \\
1989 \\
1184 \\
964 \\
104 \\
419 \\
293\end{array}$ & $\begin{array}{r}8459 \\
22563 \\
5141 \\
3106 \\
4057 \\
869 \\
502 \\
375 \\
45 \\
206\end{array}$ & $\begin{array}{r}43295 \\
6805 \\
12658 \\
1999 \\
1305 \\
1616 \\
338 \\
214 \\
123 \\
75\end{array}$ & $\begin{array}{r}14117 \\
35306 \\
4371 \\
6226 \\
915 \\
634 \\
756 \\
198 \\
110 \\
69\end{array}$ & $\begin{array}{r}23300 \\
11535 \\
22144 \\
2307 \\
3178 \\
497 \\
291 \\
375 \\
105 \\
98\end{array}$ & $\begin{array}{r}27652 \\
19068 \\
8017 \\
10872 \\
973 \\
1247 \\
186 \\
93 \\
128 \\
46\end{array}$ & $\begin{array}{r}10915 \\
22640 \\
13722 \\
3920 \\
5141 \\
497 \\
532 \\
78 \\
37 \\
81\end{array}$ & $\begin{array}{r}27721 \\
8930 \\
14064 \\
6672 \\
1506 \\
2161 \\
200 \\
214 \\
31 \\
48\end{array}$ \\
\hline $\begin{array}{l}1+ \\
2+ \\
3+\end{array}$ & $\begin{array}{l}71155 \\
43245 \\
38977\end{array}$ & $\begin{array}{l}71085 \\
47404 \\
24719\end{array}$ & $\begin{array}{l}69338 \\
48730 \\
29504\end{array}$ & $\begin{array}{l}85184 \\
43186 \\
26808\end{array}$ & $\begin{array}{l}75952 \\
58149 \\
24273\end{array}$ & $\begin{array}{l}54185 \\
44252 \\
30262\end{array}$ & $\begin{array}{l}56544 \\
28184 \\
20460\end{array}$ & $\begin{array}{l}45323 \\
36612 \\
14050\end{array}$ & $\begin{array}{l}68429 \\
24935 \\
18130\end{array}$ & $\begin{array}{l}62703 \\
48407 \\
13101\end{array}$ & $\begin{array}{l}63830 \\
40326 \\
28792\end{array}$ & $\begin{array}{l}68282 \\
40455 \\
21388\end{array}$ & $\begin{array}{l}57563 \\
46530 \\
23890\end{array}$ & $\begin{array}{l}61547 \\
33747 \\
24817\end{array}$ \\
\hline $\begin{array}{c}1 \\
2 \\
3 \\
4 \\
5 \\
6 \\
7 \\
8 \\
9 \\
10+\end{array}$ & $\begin{array}{r}17756 \\
4817 \\
47076 \\
20861 \\
9447 \\
5525 \\
8293 \\
273 \\
1311 \\
521\end{array}$ & $\begin{array}{r}18788 \\
29253 \\
5120 \\
42233 \\
16542 \\
8740 \\
6348 \\
6715 \\
108 \\
1383\end{array}$ & $\begin{array}{r}15232 \\
22659 \\
29975 \\
4889 \\
28847 \\
11415 \\
4787 \\
4439 \\
2897 \\
321\end{array}$ & $\begin{array}{r}32901 \\
19762 \\
21124 \\
21843 \\
4022 \\
18267 \\
6596 \\
2345 \\
4213 \\
2517\end{array}$ & $\begin{array}{r}11963 \\
36465 \\
20006 \\
16012 \\
17036 \\
2505 \\
10955 \\
3524 \\
1362 \\
2009\end{array}$ & $\begin{array}{r}\text { Mear } \\
8322 \\
15582 \\
31685 \\
10985 \\
8366 \\
9170 \\
1274 \\
5951 \\
1744 \\
1460\end{array}$ & $\begin{array}{r}\text { Stock Blc } \\
26245 \\
10374 \\
12282 \\
21944 \\
6876 \\
5236 \\
5555 \\
717 \\
3265 \\
3095\end{array}$ & $\begin{array}{r}\text { ness at A } \\
6849 \\
24299 \\
6939 \\
8074 \\
13491 \\
3606 \\
2736 \\
2315 \\
341 \\
1816\end{array}$ & $\begin{array}{r}36345 \\
8110 \\
22181 \\
5079 \\
5212 \\
8138 \\
2344 \\
1556 \\
1103 \\
732\end{array}$ & $\begin{array}{r}9472 \\
41787 \\
8059 \\
18982 \\
3978 \\
3399 \\
4864 \\
1481 \\
907 \\
715\end{array}$ & $\begin{array}{r}16595 \\
14707 \\
37379 \\
5425 \\
11148 \\
2100 \\
1520 \\
2291 \\
765 \\
937\end{array}$ & $\begin{array}{r}20276 \\
26257 \\
12998 \\
28864 \\
3820 \\
5622 \\
1017 \\
643 \\
1058 \\
491\end{array}$ & $\begin{array}{r}8218 \\
28100 \\
24071 \\
8888 \\
16817 \\
2064 \\
2946 \\
551 \\
311 \\
763\end{array}$ & \\
\hline $\begin{array}{l}\text { TOTBIO } \\
\text { SPWNBIO }^{\text {a }}\end{array}$ & $\begin{array}{r}115880 \\
80612\end{array}$ & $\begin{array}{r}135230 \\
89501\end{array}$ & $\begin{array}{r}125460 \\
92748\end{array}$ & $\begin{array}{r}133590 \\
86483\end{array}$ & $\begin{array}{r}121838 \\
89656\end{array}$ & $\begin{array}{l}94539 \\
78409\end{array}$ & $\begin{array}{l}95589 \\
67257\end{array}$ & $\begin{array}{l}70465 \\
55479\end{array}$ & $\begin{array}{l}90800 \\
55783\end{array}$ & $\begin{array}{l}93644 \\
66941\end{array}$ & $\begin{array}{l}92866 \\
72147 \\
\end{array}$ & $\begin{array}{r}101046 \\
70775\end{array}$ & $\begin{array}{l}92729 \\
74914\end{array}$ & \\
\hline
\end{tabular}

Spawning stock biomass is at spawnıng time (i.e. March 1).

\section{Summary}

"I used to get 2000 to 3000 pounds of (cod) fish on a tow, and l'd go fishing for eight days (on Georges Bank). Now, a fisherman will get 500 to 1000 pounds on a tow, and the trip takes twelve to thirteen days." Joe Brancaleone, 1989 (former fisherman and current member of the NEFMC), (Quoted in D. Cramer, 1989).

"If John Cabot (the English explorer who first crossed Georges Bank almost five centuries ago) were alive today, he would not recognize Georges Bank. Instead of a sea swarming with majestic cod, he would find dogfish. Instead of flounder, he would find skates. Instead of a fisherman's dream, he would find a nightmare." Congressman Gerry Studds (Massachusetts) on introducing the 'New England Groundfish Restoration Act' to the USA Congress, 1991.
The Georges Bank cod stock is a valuable natural resource and has been a central component of the New England offshore fisheries for centuries. Throughout most of this period, the cod fishery was unregulated and growth in the fishery did not appear to exceed resource potential. During the 1960s and early-1970s, when other stocks had collapsed or declined markedly due to increased fishing pressure (Brown and Halliday, 1983), the Georges Bank cod stock remained relatively stable. The stock seemed resilient to heavy exploitation until the earlyand mid-1980s when (under extended fisheries jurisdiction), landings, fishing effort and fishing mortality approached or attained record-high levels. Spawning stock biomass declined by $40 \%$ between 1980 and 1985/86 despite good recruitment, as growth and spawning potential of good year-classes were mortgaged for short-term yield. As a bellwether of the status of the entire groundfish complex 
on Georges Bank, the decline in cod raised serious concerns on the effectiveness of fisheries conservation programs in both the USA and Canada. Lack of compatible approaches between the two countries on the management of Georges Bank stocks exacerbated the situation and fostered, to some degree, competitive overfishing. Overlapping fisheries jurisdictional claims were not resolved until October 1984; shortly thereafter, independently conducted USA and Canadian assessments began to reveal the impacts that 'supervised neglect' (Jensen, 1973) was having on the Georges Bank cod stock.

Both the USA and Canada now recognize that cooperative and coordinated management actions are required to rebuild transboundary stocks (including Georges Bank cod) and prevent overfishing. The future of the groundfish fishing industries in both countries will critically depend on the success of these initiatives.

\section{Acknowledgements}

We thank R. Mayo and S. Clark (Northeast Fisheries Center, Woods Hole, Massachusetts) for their constructive comments and valuable advice during preparation of the manuscript. We are also grateful for the suggestions made for improving the manuscript by R. Halliday, J. Hunt and an anonymous reviewer.

\section{References}

ALEXANDER, A.B., H.F. MOORE, and W.C. KENDALL. 1915. Otter-trawl fishery. Rep. U.S. Comm. Fish. 1914, Appendix VI, $97 \mathrm{p}$.

ANTHONY, V.C. 1990. The New England groundfish fishery after 10 years under the Magnuson Fishery Conservation and Management Act. North. Amer. J. Fish. Mgmt., 10: 175-184.

AZAROVITZ, T.R. 1981. A brief historical review of the Woods Hole Laboratory trawl survey time series. In: Bottom Trawl Surveys. W.G. Doubleday and D. Rivard (eds.). Can. Spec. Publ. Fish. Aquat. Sci. 58: 62-67.

BAIRD, S.F. 1873. Report of the Commissioner for 18711872. U.S. Comm. Fish and Fish. Part I.

1874. Conclusions as to decrease of cod-fisheries on the New England coast. U.S. Comm. Fish and Fish., Part 2, Rep. Comm, 1872 and 1873: xi-xiv.

BERRIEN, P.L., M.P. FAHAY, A.W. KENDALL, Jr., and W.G. SMITH. 1978. Ichthyoplankton from the RV Dolphin survey of continental shelf waters between Martha's Vineyard, Massachusetts and Cape Lookout, North Carolina, 1965-66. Tech. Series Rept. 15, Sandy Hook Lab., NEFC, NMFS, Highlands, New Jersey.

BOWEN, D. (ed.). MS 1987. A review of stock structure in the Gulf of Maine area: A workshop report. CAFSAC Res. Doc., No. 21, $51 \mathrm{p}$.

BRERETON, J. 1602. A brief and true relation of the discovery of the North part of Virginia. Excerpt reprinted in: Pearson, J. C. 1972. The fish and fisheries of colonial North America. A documentary history of the fishing resources of the United States and Canada.
Part II. The New England States, p. 180. National Technical Information Service, Springfield, Virginia, p. 178-678.

BROWN, B.E. MS 1971. A preliminary review of the status of the Subarea 5 cod stock. ICNAFRes. Doc. No. 125, Serial No. 2623, 14 p.

BROWN, B. E., J. A. BRENNAN, E. G. HEYERDAHL, M. D. GROSSLEIN, and R. C. HENNEMUTH. 1976. The effect of fishing on the marine biomass of the Northwest Atlantic from the Gulf of Maine to Cape Hatteras. ICNAF Res. Bull., 12: 49-68.

BROWN, B.E., and R.G. HALLIDAY. 1983. Fisheries resources of the Northwest Atlantic - Some responses to extreme fishing perturbations, p. 96-109. In: Proceedings of the Joint Oceanographic Assembly 1982, General Assembly. Canadian National Committee/Scientific Committee on Oceanic Research, Ottawa.

BROWN, B.E., and E.G. HEYERDAHL. MS 1972. An assessment of the Georges Bank cod stock (Div. 5Z). ICNAF Res. Doc. No. 117, Serial No. 2831, 24 p.

BURNS, T.S., R. SCHULTZ, and B.E. BROWN. 1983. The commercial catch sampling program in the northeastern United States, In:W. G. Doubleday, and D. Rivard (eds.) Sampling Commercial Catches of Marine Fish and Invertebrates, Can. Spec. Pub. Fish Aquat. Sci., 66: 82-95.

CAFSAC MS 1987. Further advice on the management of groundfish stocks in 1988. CAFSAC Adv. Doc., No. 21, $44 \mathrm{p}$.

MS 1988. Further advice on the management of groundfish stocks in 1989. CAFSAC Adv. Doc., No. 25, $30 \mathrm{p}$.

MS 1989. Advice on the management of groundfish stocks in 1990. CAFSAC Adv. Doc., No. 12, 82 p.

CHRISTIE, D.R. 1987. The Georges Bank/Gulf of Maine boundary dispute between the United States and Canada. In: Georges Bank, R. H. Backus (ed.). The MIT Press, Cambridge, Massachusetts, p. 469-473.

CLARK, S.H. 1979. Application of bottom trawl survey data to fish stock assessments. Fisheries, 4: 9-15.

CLARK, S.H., and B.E. BROWN. 1977. Changes in biomass of finfishes and squids from the Gulf of Maine to Cape Hatteras, 1963-74, as determined from research vessel survey data. Fish. Bull. U.S., 75(1): 121.

CLARK, S. H., and B. E. BROWN. 1979. Trends in biomass of finfishes and squids in ICNAF Subarea 5 and Statistical Area 6, 1964-1977, as determined from research vessel survey data. Invest. Pesq., 43(1): 107-122.

CLARK, S.H., W.J. OVERHOLTZ, and R.C. HENNEMUTH. 1982. Review and assessment of the Georges Bank and Gulf of Maine haddock fishery. J. Northw. Atl. Fish. Sci., 3: 1-27.

COLTON, J.B., W.G. SMITH, A.W. KENDALL, P.L. BERRIEN, and M.P. FAHAY. 1979. Principal spawning areas and times of marine fishes, Cape Sable to Cape Hatteras. Fish. Bull. U.S., 76: 911-915.

CRAMER, D. 1989. Fished out. Sanctuary (a publication of the Massachusetts Audubon Society), July/August 1989: 5-8.

FISH, C.J. 1928. Production and distribution of cod eggs in Massachusetts Bay in 1924 and 1925. Bull. U.S. Bur. Fish, 43 (Part II): 253-296.

FOGARTY, M.J., R.K. MAYO, F.M. SERCHUK, and F.P. ALMEIDA. MS 1989. Trends in aggregate fish biom- 
ass and production on Georges Bank. NAFO SCR. Doc., No. 78, Serial No. N1662, 23 p.

GABRIEL, W.L., M.P. SISSENWINE, and W.J. OVERHOLTZ. 1989. Analysis of spawning stock biomass per recruit: an example for Georges Bank haddock. North. Amer. J. Fish. Mgmt., 9: 383-391.

GERMAN, A.W. 1987. History of the early fisheries: 1720 1930. In: Georges Bank, R. H. Backus (ed.). The MIT Press, Cambridge, Massachusetts, p. 409-424.

GOODE, G.B., and J.W. COLLINS. 1887. The George's Bank cod fishery, p. 187-198. In: The Fisheries and Fishery Industries of the United States, G.B. Goode (ed.). Section V, History and Methods of the Fisheries, Vol. 1, Part II, The Cod, Haddock, and Hake Fisheries. Washington, D.C.

GRAHAM, H.W. 1952. A regulation to increase the yield of the New England haddock fishery. Trans. Seventeenth North Amer. Wildl. Conf., March 17-19 1952: 378-385.

1970. Management of the groundfish fisheries of the Northwest Atlantic. In: A Century of Fisheries in North America. N.G. Benson (ed.). Amer. Fish. Soc., Spec. Pub., 7: 249-261.

GROSSLEIN, M.D. 1969. GROUNDfish survey program of BCF Woods Hole. Comm. Fish. Rev., 31(8-9): 22-35.

HACHÉ, J.-E. (Chairman). 1989. Report of the ScotiaFundy Groundfish Task Force. Department of Fisheries and Oceans. Cat No. Fs 23-157/1989E, 86 p.

HALLIDAY, R.G., and A.T. PINHORN. 1990. The delimitation of fishing areas in the Northwest Atlantic. J. Northw. Atl. Fish. Sci., 10: 1-51.

HENNEMUTH, R.C. MS 1969. Status of the Georges Bank haddock fishery. ICNAF Res. Doc., No. 90, Serial No. 2256, $21 \mathrm{p}$

HENNEMUTH, R.C., and S. ROCKWELL. 1987. History of fisheries conservation and management. In: Georges Bank. R. H. Backus, (ed.). The MIT Press, Cambridge, Massachusetts, p. 430-436.

HERRINGTON, W.C. 1932. Conservation of immature fish in otter trawling. Trans. Amer. Fish. Soc., 62: 57-63.

1935. Modifications in gear to curtail the destruction of undersized fish in otter trawling. U.S. Bur. Fish., Invest. Rep., 24: 48 p.

HEYERDAHL, E.G. MS 1972. Estimates of future abundance levels of cod stocks in ICNAF Subarea 5 based on U.S. research survey cruise indices. ICNAF Res. Doc., No. 115, Serial No. 2830, 4 p.

HUNT, J.J. MS 1987. Status of the Atlantic cod stock on Georges Bank, NAFO Division $5 Z$ and Subarea 6, in 1986. CAFSAC Res. Doc. No. 94, 53 p.

MS 1988. Status of the Atlantic cod stock on Georges Bank, NAFO Division $5 Z$ and Subarea 6, in 1987. CAFSAC Res. Doc., No. 73, 50 p.

MS 1989. Status of the Atlantic cod stock on Georges Bank in unit areas 5Zj and 5Zm, 197888. CAFSAC Res. Doc., No. 47, 26 p.

MS 1990. Status of the Atlantic cod stock on Georges Bank in unit areas 5Zj and 5Zm, 197889.CAFSAC Res. Doc., No. 80, 37 p.

HUNT, J.J., M-I. BUZETA, and J.D. NIELSON. MS 1991. Status of the Atlantic cod stock on Georges Bank in unit areas 5Zj and 5Zm, 1978-90. CAFSAC Res. Doc., No. 41, $21 \mathrm{p}$.

HUNT, J.J., and S. GAVARIS. MS 1986. Status of the Atlantic cod stock on Georges Bank, NAFO Division $5 Z$ and Statistical Area 6, in 1985. CAFSAC Res. Doc., No. 95, 49 p.
HUNT, J.J., and K.G. WAIWOOD. MS 1984. Status of the Atlantic cod stock on Georges Bank, NAFO Division $5 Z$ and Statistical Area 6, in 1983. CAFSAC Res. Doc., No. 65, 32 p.

MS 1985. Status of the Atlantic cod stock on Georges Bank, NAFO Division $5 Z$ and Statistical Area 6, in 1984. CAFSAC Res. Doc., No. 87, 47 p.

HURLEY, P.C.F., and R.N. O'BOYLE. MS 1983. An evaluation of the current $5 Z$ cod population characteristics during 1960-82 with yield projected to 1984. CAFSAC Res. Doc., No. 77, 32 p.

ICNAF. 1971-76. Standing Committee on Research and Statistics. Report of Assessments Subcommittee. ICNAF Redbooks, 1971-76.

JENSEN, A.C. 1967. A brief history of the New England offshore fisheries. U.S. Bur. Comm. Fish., Fish. Leafl., 594: $14 \mathrm{p}$.

1968. Atlantic cod.... beef of the sea. Atl. States Mar. Fish. Comm., Mar. Resour. of the Atl. Coast, Leafl., 10: 4 p.

1972. The Cod. Thomas Y. Crowell Co., New York, $182 \mathrm{p}$.

1973. The Cod: A case of supervised neglect. Nat. Hist., 82(1): 44-51.

1974. Sport fishing for cod. N.Y. Fish Game J., 23: $138-148$.

JENSEN, A.C., and H.E. MURRAY. 1965. The U.S. cod fishery in the Northwest Atlantic. Comm. Fish. Rev., 27(7): 1-11.

LINCOLN, Hon. General. 1791. A letter from the Hon. General Lincoln to the Author: Hingham, Dec. 12, 1791. Printed in: Belknap, J. 1813. The history of New Hampshire. Bradford and Read, Boston. Reprinted in: Pearson, J. C. 1972. The fish and fisheries of colonial North America. A documentary history of the fishing resources of the United States and Canada. Part II. The New England States, p. 217-221. National Technical Information Service, Springfield, Virginia, p. 178-678.

MARCHESSEAULT, G.D., R.P. RUAIS, and D. WANG. MS 1980. History and status of the Atlantic Demersal Finfish Fishery Management Plan. NOAA Tech. Mem. NMFS-F/NEC-2, $15 \mathrm{p}$.

MAYO, R.K. MS 1977. Historical description of the Northeast Fisheries Center statistical area data base. NMFS, NEFC, Woods Hole Lab. Ref. Doc., No. 77-19: $8 \mathrm{p}$.

MOGTF. 1990. New England Groundfish in Crisis - Again. The Report of the Massachusetts Offshore Groundfish Task Force, December 1990, 33 p.

NEFC. MS 1986. Report of Third NEFC Stock Assessment Workshop (Third SAW). NMFS, NEFC, Woods Hole Lab., Ref Doc., No. 86-14: 98 p.

MS 1987. Status of mixed species demersal finfish resources in New England and scientific basis for management. NMFS, NEFC, Woods Hole Lab. Ref. Doc., No. 87-08: $104 \mathrm{p}$.

MS 1989. Report of Seventh NEFC Stock Assessment Workshop (Seventh SAW). NMFS, NEFC, Woods Hole Lab., Ref. Doc., No. 89-04: 108 p.

MS 1990. Report of Eleventh NEFC Stock Assessment Workshop, Fall 1990. NMFS, NEFC Ref. Doc., No. 90-09: $121 \mathrm{p}$.

MS 1991. Report of the Twelfth Northeast Regional Stock Assessment Workshop (12th SAW), Spring 1991. NMFS, NEFC Ref. Doc., No. 91-03: $187 \mathrm{p}$. 
MS 1992. Report of the Thirteenth Northeast Regional Stock Assessment Workshop (13th SAW). NMFS, NEFC Ref. Doc., No. 92-02: 175 p.

NEFMC. 1977. Fishery Management Plan for Atlantic Groundfish. New England Fishery Management Council, Peabody, Massachusetts, $148 \mathrm{p}$.

1981. Interim Fishery Management Plan for Atlantic Groundfish. New England Fishery Management Council, Saugus, Massachusetts, $101 \mathrm{p}$.

1985. Fishery Management Plan for the Northeast Multi-Species Fishery. New England Fishery Management Council, Saugus, Massachusetts.

NORTH AMERICAN COUNCIL ON FISHERY INVESTIGATIONS. 1932. Proceedings for 1921-1930, No. 1, $56 \mathrm{p}$.

1935. Proceedings for 1931-1933, No. 2, 40 p.

PENTTILA, J.A., AND V.M. GIFFORD. 1976. Growth and mortality rates of cod from the Georges Bank and Gulf of Maine areas. ICNAF Res. Bull.,12: 29-36.

PIERCE, D.E. 1982. Development and evolution of fishery management plans for cod, haddock, and yellowtail flounder. Massachusetts Div. Mar. Fish. Publ. 13233133-50-5-83-CR, $133 \mathrm{p}$.

PINHORN, A.T., and R.G. HALLIDAY. 1990. Canadian versus international regulation of Northwest Atlantic fisheries: Management practices, fishery yields, and resource trends, 1960-1986. North Amer. J. Fish. Mgmt., 10: 154-174.

RECREATIONAL FISHERY STATISTICS WORKING GROUP. MS 1992. MRFSS (Marine Recreational Fishery Statistics Survey) catch statistics for Atlantic cod. 13th Northeast Regional Stock Assessment Workshop, Plenary Working Paper No. 2: $11 \mathrm{p}$

ROUNSEFELL, G.A. 1948. Development of fishery statistics in the North Atlantic. U.S. Fish Wildl. Serv., Spec. Sci. Rep., 47: 27 p.

RYAN, J.J. 1979. The cod family and its utilization. Mar. Fish. Rev., 41(11): 25-36.

SCOTT, W.B., and M.G. SCOTT. 1988. Atlantic Fishes of Canada. Can. Bull. Fish. Aquat. Sci., 219: 731 p.

SCHROEDER, W.C. 1930. Migrations and other phases in the life history of the cod off Southern New England. Bull. U.S. Bur. Fish., 46: $136 \mathrm{p}$.

SERCHUK, F.M. MS 1988. Status and assessment of the Georges Bank and Gulf of Maine cod stocks, 1988. Seventh Northeast Fisheries Center (Woods Hole, MA) Stock Assessment Workshop, Working Paper No. 1: $60 \mathrm{p}$

SERCHUK, F.M., S.H. CLARK, and B.E. BROWN. MS 1981. Implications of the 1981 Georges Bank and Gulf of Maine cod and haddock assessments for future management strategies. NMFS, NEFC, Woods Hole Lab. Ref. Doc., No. 81-09: 7 p.

SERCHUK, F.M., R.K. MAYO, S.E. WIGLEY, L. O'BRIEN, and N. BUXTON. MS 1991. Revised assessment of the Georges Bank cod stock. 13th Northeast Regional Stock Assessment Workshop, Working Paper No. 18.

SERCHUK, F.M., R.S. RAK, and J. PENTTILA. MS 1982. Status of the Georges Bank and Gulf of Maine Atlantic cod stocks - 1982. NMFS, NEFC, Woods Hole Lab. Ref. Doc., No. 82-33: 46 p.

SERCHUK, F.M., and S.E. WIGLEY. MS 1986. Assess- ment and status of the Georges Bank and Gulf of Maine Atlantic cod stocks. NMFS, NEFC, Woods Hole Lab. Ref. Doc., No. 86-12: 84 p.

MS 1990. Revised assessment of the Georges Bank cod stock, 1990. 11th Northeast Fisheries Center (Woods Hole, MA) Stock Assessment Workshop, Working Paper No. 1: $42 \mathrm{p}$

SERCHUK, F.M., and P.W. WOOD. MS 1979. Review and status of the Southern New England-Middle Atlantic cod, Gadus morhua, populations. August 1979. NMFS, NEFC, Woods Hole Lab. Ref. Doc., No. 79-37: $77 \mathrm{p}$

SERCHUK, F.M., and P.W. WOOD, Jr. MS 1981. Assessment and status of the Georges Bank and Gulf of Maine Atlantic cod stocks - 1981. NMFS, NEFC, Woods Hole Lab. Ref. Doc., No. 81-06: $67 \mathrm{p}$.

SERCHUK, F.M., P.W. WOOD, and B.E. BROWN. MS 1978. Atlantic cod (Gadus morhua): Assessment and status of the Georges Bank and Gulf of Maine stocks. January 1978. NMFS, NEFC, Woods Hole Lab. Ref. Doc., No. 78-03: 25 p.

SERCHUK, F.M., P.W. WOOD, S.H. CLARK, and B.E. BROWN. MS 1977. Analysis of the Georges Bank and Gulf of Maine cod stocks. NMFS, NEFC, Woods Hole Lab. Ref. Doc., No. 77-24: 26 p.

SERCHUK, F.M., P.W. WOOD, Jr., and D.M. FRIED. MS 1980. Current assessment and status of the Georges Bank and Gulf of Maine cod stocks. NMFS, NEFC, Woods Hole Lab. Ref. Doc., No. 80-07: 52 p.

SERCHUK, F.M., P.W. WOOD, R. LEWIS, J.A. PENTTILA, and B.E. BROWN. MS 1979. Status of the Georges Bank and Gulf of Maine cod stocks. February 1979. NMFS, NEFC, Woods Hole Lab. Ref. Doc., No. 79-10: $32 \mathrm{p}$.

SETTE, O.E. 1928. Statistics of the catch of cod off the east coast of North America to 1926. Rept. U.S. Comm. Fish. for 1927, with Appendices: 737-748.

SETTE, O.E., and R.H. FIEDLER. 1929. Fishery industries of the United States, 1927. Rept. U.S. Comm. Fish. for 1928, with Appendices, Part I: 401-547.

SHERMAN, K., and J.P. WISE. 1961. Incidence of the cod parasite, Lernaeocera branchialis, in the New England area, and its possible use as an indicator of cod populations. Limnol. Oceanogr., 6: 61-67.

SMITH, H.M. 1902. Notes on tagging of 4,000 adult cod at Woods Hole, Mass. Rept. U.S. Fish. Comm., 27: 193-208.

STUDDS, G. E. 1991. Introduction of New England groundfish restoration act (H.R. 2919). USA Congressional Record, July 16, 1991, p. H-5494.

TMG. 1988. An assessment of the effectiveness of the Northeast Multispecies FMP with recommendations for plan and management system improvements. Report to the New England Fishery Council's Demersal Finfish Committee, $40 \mathrm{p}$.

U.S. DEPARTMENT OF COMMERCE. 1979. FISHERIES OF THE UNITED STATES, 1978. NMFS, Current Fish. Stat., No. $7800,120 \mathrm{p}$.

WISE, J.P. 1958. The world's southernmost indigenous cod. ICES J. Cons., 23: 208-212.

1963. Cod groups in the New England area. Fish. Bull. U.S., 63: 189-203. 